\title{
Kinetic double-layer model of aerosol surface chemistry and gas-particle interactions (K2-SURF): Degradation of polycyclic aromatic hydrocarbons exposed to $\mathrm{O}_{3}, \mathrm{NO}_{2}, \mathrm{H}_{2} \mathrm{O}, \mathrm{OH}$ and $\mathrm{NO}_{3}$
}

\author{
M. Shiraiwa, R. M. Garland, and U. Pöschl \\ Max Planck Institute for Chemistry, Biogeochemistry Department, P.O. Box 3060, 55128 Mainz, Germany
}

Received: 7 August 2009 - Published in Atmos. Chem. Phys. Discuss.: 1 September 2009

Revised: 7 December 2009 - Accepted: 8 December 2009 - Published: 21 December 2009

\begin{abstract}
We present a kinetic double-layer surface model (K2-SURF) that describes the degradation of polycyclic aromatic hydrocarbons (PAHs) on aerosol particles exposed to ozone, nitrogen dioxide, water vapor, hydroxyl and nitrate radicals. The model is based on multiple experimental studies of PAH degradation and on the PRA framework (PöschlRudich-Ammann, 2007) for aerosol and cloud surface chemistry and gas-particle interactions.

For a wide range of substrates, including solid and liquid organic and inorganic substances (soot, silica, sodium chloride, octanol/decanol, organic acids, etc.), the concentrationand time-dependence of the heterogeneous reaction between PAHs and $\mathrm{O}_{3}$ can be efficiently described with a LangmuirHinshelwood-type mechanism. Depending on the substrate material, the Langmuir adsorption constants for $\mathrm{O}_{3}$ vary over three orders of magnitude $\left(K_{\mathrm{ads}, \mathrm{O} 3} \approx 10^{-15}-10^{-13} \mathrm{~cm}^{3}\right)$, and the second-order rate coefficients for the surface layer reaction of $\mathrm{O}_{3}$ with different $\mathrm{PAH}$ vary over two orders of magnitude $\left(k_{\mathrm{SLR}, \mathrm{PAH}, \mathrm{O} 3} \approx 10^{-18}-10^{-17} \mathrm{~cm}^{2} \mathrm{~s}^{-1}\right)$. The available data indicate that the Langmuir adsorption constants for $\mathrm{NO}_{2}$ are similar to those of $\mathrm{O}_{3}$, while those of $\mathrm{H}_{2} \mathrm{O}$ are several orders of magnitude smaller $\left(K_{\text {ads, } \mathrm{H} 2 \mathrm{O}} \approx 10^{-18}-10^{-17} \mathrm{~cm}^{3}\right)$. The desorption lifetimes and adsorption enthalpies inferred from the Langmuir adsorption constants suggest chemisorption of $\mathrm{NO}_{2}$ and $\mathrm{O}_{3}$ and physisorption of $\mathrm{H}_{2} \mathrm{O}$. Note, however, that the exact reaction mechanisms, rate limiting steps and possible intermediates still remain to be resolved (e.g., surface diffusion and formation of $\mathrm{O}$ atoms or $\mathrm{O}_{3}^{-}$ions at the surface).
\end{abstract}

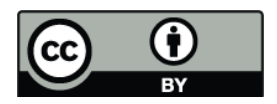

Correspondence to: $\mathrm{M}$. Shiraiwa (m.shiraiwa@mpic.de)
The K2-SURF model enables the calculation of ozone uptake coefficients, $\gamma_{\mathrm{O} 3}$, and of $\mathrm{PAH}$ concentrations in the quasi-static particle surface layer. Competitive adsorption and chemical transformation of the surface (aging) lead to a strong non-linear dependence of $\gamma_{\mathrm{O} 3}$ on time and gas phase composition, with different characteristics under dilute atmospheric and concentrated laboratory conditions. Under typical ambient conditions, $\gamma_{\mathrm{O} 3}$ of $\mathrm{PAH}-$ coated aerosol particles are expected to be in the range of $10^{-6}-10^{-5}$.

At ambient temperatures, $\mathrm{NO}_{2}$ alone does not efficiently degrade PAHs, but it was found to accelerate the degradation of PAHs exposed to $\mathrm{O}_{3}$. The accelerating effect can be attributed to highly reactive $\mathrm{NO}_{3}$ radicals formed in the gas phase or on the surface. Estimated second-order rate coefficients for $\mathrm{O}_{3}-\mathrm{NO}_{2}$ and $\mathrm{PAH}-\mathrm{NO}_{3}$ surface layer reactions are in the range of $10^{-17}-10^{-16} \mathrm{~cm}^{2} \mathrm{~s}^{-1}$ and $10^{-15}$ $10^{-12} \mathrm{~cm}^{2} \mathrm{~s}^{-1}$, respectively.

The chemical half-life of PAHs is expected to range from a few minutes on the surface of soot to multiple hours on organic and inorganic solid particles and days on liquid particles. On soot, the degradation of particle-bound PAHs in the atmosphere appears to be dominated by a surface layer reaction with adsorbed ozone. On other substrates, it is likely dominated by gas-surface reactions with $\mathrm{OH}$ or $\mathrm{NO}_{3}$ radicals (Eley-Rideal-type mechanism).

To our knowledge, K2-SURF is the first atmospheric process model describing multiple types of parallel and sequential surface reactions between multiple gaseous and particlebound chemical species. It illustrates how the general equations of the PRA framework can be simplified and adapted for specific reaction systems, and we suggest that it may serve as a basis for the development of a general master mechanism of aerosol and cloud surface chemistry. 


\section{Introduction}

Aerosols are ubiquitous in the atmosphere and have strong effects on climate and public health. Depending on chemical composition and surface properties, aerosol particles can act as condensation nuclei for cloud droplets and ice crystals, and they can influence trace gas concentrations through heterogeneous chemical reactions (Seinfeld and Pandis, 1998; Pöschl, 2005; Fuzzi et al., 2006; Andreae and Rosenfeld, 2008; Hallquist et al., 2009). Polycyclic aromatic hydrocarbons (PAHs) are one of the most prominent groups of toxic air pollutants. They originate from biomass burning and fossil fuel combustion, and they reside to a large extent in fine air particulate matter that can penetrate deep into human lungs (Finlayson-Pitts and Pitts, 2000; Pöschl, 2002; Schauer et al., 2003). Chemical degradation and transformation (oxidation or nitration) can change the surface properties of aerosol particles and the toxicity of PAH (Pitts, 1983; Atkinson and Arey, 1994; Pöschl, 2002; Schauer et al., 2004; Pöschl et al., 2007).

Moreover, PAH as well as its oxygenated or nitrated derivatives are well defined model substances for the molecular structure of soot, which is the black solid product of incomplete combustion or pyrolysis of organic matter (Homann, 1998; Messerer et al., 2005; Pöschl, 2005; Sadezky et al., 2005). Soot contributes to regional and global climate change because of its role in direct, indirect and semi-direct radiative forcing (Hansen et al., 1997; Ackerman et al., 2000; Jacobson, 2000). Upon emission from combustion sources, fresh soot is initially hydrophobic and mostly externally mixed with non-refractory compounds (Shiraiwa et al., 2007; Schwarz et al., 2008). However, condensation of semi-volatile compounds and chemical processing by ozone and other oxidants can make soot particles hydrophilic (Mikhailov et al., 2006) and influence their ability to act as cloud condensation nuclei (Kuwata et al., 2007). Furthermore, chemical reactions with atmospheric photo-oxidants can lead to substantial degradation, short-term and seasonal variations, and measurement artefacts in the determination of PAHs (Schauer et al., 2003, 2004; Marchand et al., 2004; Liu et al., 2006; Lee and Kim, 2007; Lammel et al., 2009).

As detailed below (Sect. 3), several laboratory studies have investigated the heterogeneous reaction of PAHs on various substrates with ozone, nitrogen dioxide, water vapour, hydroxyl and nitrate radicals. So far, however, the experimental results had not yet been compiled in a form that enables efficient modelling of PAH degradation in different types of reaction systems and direct comparison of relevant physicochemical parameters (accommodation, uptake, and reaction rate coefficients; adsorption constants; etc.).

Recently, Springmann et al. (2009) have demonstrated the applicability and usefulness of the PRA framework (Ammann and Pöschl, 2007; Pöschl et al., 2007) for atmospheric modeling of the degradation of benzo[a]pyrene on soot by ozone and nitrogen dioxide. In this study we show that the
PRA model approach can be efficiently extended to other PAHs and photo-oxidants. Within the European integrated project on aerosol, cloud, climate and air quality interactions (EUCAARI, Kulmala et al., 2009), we have reviewed and synthesized available literature data to develop a reaction mechanism describing the degradation of PAHs exposed to $\mathrm{O}_{3}, \mathrm{NO}_{2}, \mathrm{H}_{2} \mathrm{O}, \mathrm{OH}$ and $\mathrm{NO}_{3}$ radicals in a kinetic doublelayer surface model (K2-SURF). PAH degradation and related ozone uptake are simulated over a wide range of conditions, and the atmospheric implications are discussed.

\section{Model description}

The K2-SURF model is based on the PRA framework for aerosol and cloud surface chemistry and gas-particle interactions (Pöschl, Rudich and Ammann 2007; Ammann and Pöschl 2007). This framework describes the gas-particle interface by several model compartments and molecular layers in which volatile, semi-volatile and non-volatile species can undergo mass transport and chemical reactions: gas phase, near-surface gas phase, sorption layer, quasi-static surface layer, and (near-surface) bulk of the particle.

As illustrated in Fig. 1, the K2-SURF model does not consider semi-volatile species and processes in the particle bulk, which is just regarded as a substrate that may influence the properties of the quasi-static surface layer.

In describing the degradation of particle-bound polycyclic aromatic hydrocarbons (PAHs) exposed to $\mathrm{O}_{3}, \mathrm{H}_{2} \mathrm{O}, \mathrm{NO}_{2}$, $\mathrm{OH}$, and $\mathrm{NO}_{3}$, the focus was on the gas phase diffusion, gas-surface mass transport, surface layer reactions, and gassurface reactions, which are discussed in following sections. We assumed that the effects of surface-bulk mass transport and chemical reactions in the bulk are negligible compared to gas-surface mass transport and chemical reactions at the surface. Nevertheless, the chemical species in the quasistatic surface layer (PAH) can interact with the near-surface particle bulk (substrate), which may influence the effective physicochemical properties of the quasi-static surface layer and related kinetic parameters such as surface accommodation coefficients, desorption lifetimes, and surface reaction rate coefficients (Pöschl et al. 2007).

\subsection{Gas phase diffusion and gas-surface mass transport}

Based on kinetic theory, the gas kinetic flux of $\mathrm{X}_{i}$ colliding with the surface $J_{\text {coll, Xi }}$ can be expressed as

$J_{\mathrm{coll}, \mathrm{X} i}=\left[\mathrm{X}_{i}\right]_{\mathrm{gs}} \omega_{\mathrm{X} i} / 4$

where $\left[\mathrm{X}_{i}\right]_{\mathrm{gs}}$ is near-surface gas phase concentration of $\mathrm{X}_{i}$ and $\omega_{\mathrm{X} i}$ is mean thermal velocity given by $\omega_{\mathrm{X} i}=\left(8 R T /\left(\pi M_{\mathrm{X} i}\right)\right)^{1 / 2}$, where $M_{\mathrm{X} i}$ is the molar mass of $\mathrm{X}_{i}, R$ is the gas constant, and $T$ is the absolute temperature. Here we assume that the gas phase concentrations of $\mathrm{O}_{3}, \mathrm{H}_{2} \mathrm{O}$, and $\mathrm{NO}_{2}$ are homogeneous throughout gas phase 


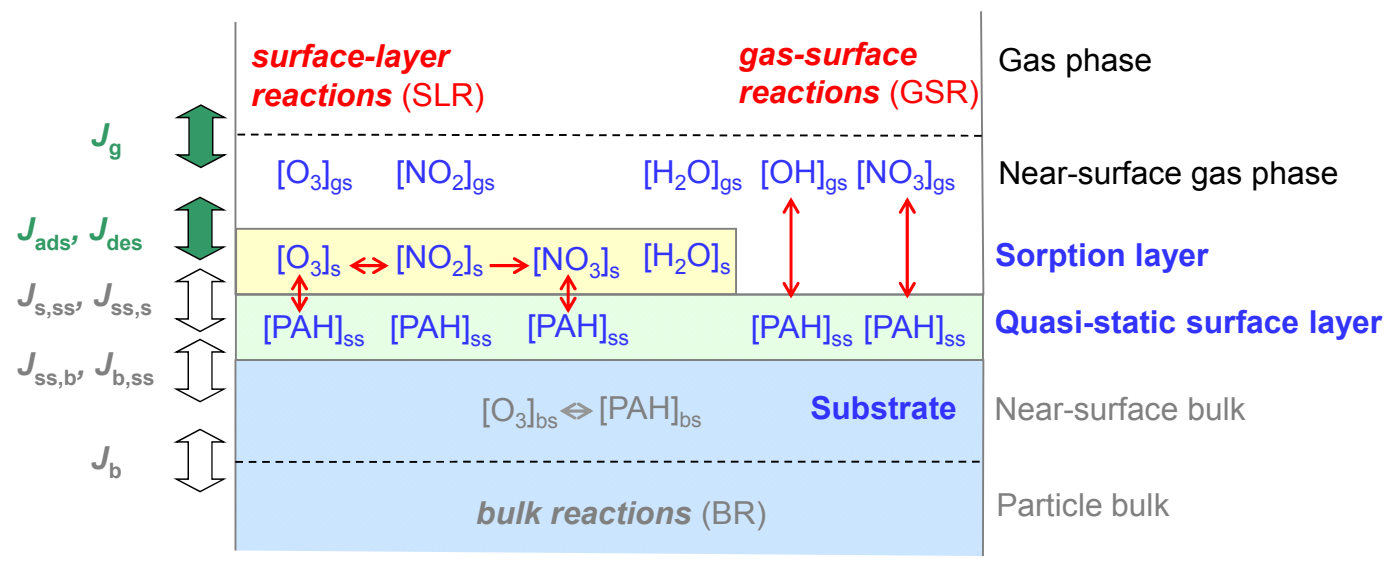

Fig. 1. Schematic illustration of the kinetic double-layer surface model (K2-SURF). Compartments, transport fluxes (thick green arrows), and chemical reactions (thin red arrows) of volatile species $\left(\mathrm{O}_{3}, \mathrm{H}_{2} \mathrm{O}, \mathrm{NO}_{2}, \mathrm{OH}\right.$ and $\left.\mathrm{NO}_{3}\right)$ and non-volatile species (PAHs).

and near-surface gas phase $\left(\left[\mathrm{X}_{i}\right]_{\mathrm{gs}}=\left[\mathrm{X}_{i}\right]_{\mathrm{g}}\right)$. This assumption is well justified when uptake coefficients are below $10^{-3}$ (Ammann and Pöschl, 2007).

On the other hand, uptake of $\mathrm{OH}$ and $\mathrm{NO}_{3}$ by PAH is reported to be high (>0.1) (Bertram et al., 2001; Gross and Bertram, 2008), therefore, the significant net uptake of $\mathrm{OH}$ and $\mathrm{NO}_{3}$ will lead to local depletion of concentration at nearsurface gas phase $\left(\left[\mathrm{X}_{i}\right]_{\mathrm{gs}}<\left[\mathrm{X}_{i}\right]_{\mathrm{g}}\right)$ and gas phase diffusion will influence further uptake. In this case near-surface gas phase concentration should be corrected using a gas phase diffusion correction factor $C_{\mathrm{g}, \mathrm{X} i}$.

$\left[\mathrm{X}_{i}\right]_{\mathrm{gs}}=C_{\mathrm{g}, \mathrm{Xi}}\left[\mathrm{X}_{i}\right]_{\mathrm{g}}$

$C_{\mathrm{g}, \mathrm{X} i}$ can be described as follows based on PRA framework (Pöschl et al., 2007).

$C_{\mathrm{g}, \mathrm{X}_{i}}=\frac{1}{1+\gamma_{\mathrm{X}_{i}} \frac{0.75+0.28 K n_{\mathrm{X}_{i}}}{K n_{\mathrm{X}_{i}}\left(1+K n_{\mathrm{X}_{i}}\right)}}$

$K n_{\mathrm{X} i}$ is Knudsen number which can be approximated by gas phase diffusion coefficient $D_{\mathrm{g}, \mathrm{X} i}$ and particle diameter $\mathrm{d}_{\mathrm{p}}$.

$K n_{\mathrm{X}_{i}}=\frac{6 D_{\mathrm{g}, \mathrm{X}_{i}}}{\omega_{\mathrm{X}_{i}} d_{\mathrm{p}}}$

We calculated $C_{\mathrm{g}, \mathrm{OH}}$ and $C_{\mathrm{g}, \mathrm{NO} 3}$ using the reported values of $D_{\mathrm{g}, \mathrm{OH}}=217 \mathrm{hPa} \mathrm{cm}^{2} \mathrm{~s}^{-1}$ (Ivanov et al., 2007), $\gamma_{\mathrm{OH}}=0.32$ (Bertram et al., 2001), $D_{\mathrm{g}, \mathrm{NO} 3}=107 \mathrm{hPa} \mathrm{cm}^{2} \mathrm{~s}^{-1}$ (Rudich et al., 1996) and $\gamma_{\mathrm{NO} 3}=0.13$ (Gross and Bertram, 2008). Figure 2 illustrates the decrease of $C_{\mathrm{g}, \mathrm{OH}}$ and $C_{\mathrm{g}, \mathrm{NO} 3}$ with increasing $d_{\mathrm{p}}$, i.e., how the effect of gas diffusion increases with increasing particle diameter.

The flux of adsorption of gas molecules on the quasi-static particle surface can be expressed as

$J_{\mathrm{ads}, \mathrm{X} i}=\alpha_{\mathrm{s}, \mathrm{X} i} J_{\mathrm{coll}, \mathrm{X} i}=k_{\mathrm{a}, \mathrm{X} i}\left[\mathrm{X}_{i}\right]_{\mathrm{gs}}$ where $\alpha_{\mathrm{s}, \mathrm{X} i}$ is surface accommodation coefficient and $k_{\mathrm{a}, \mathrm{X} i}$ $\left(=\alpha_{\mathrm{s}, \mathrm{X} i} \omega_{\mathrm{X} i} / 4\right)$ is a first-order adsorption rate coefficient. In Langmuir adsorption model, $\alpha_{\mathrm{s}, \mathrm{X} i}$ is determined by the surface accommodation coefficient on an adsorbate-free surface $\alpha_{\mathrm{s}, 0, \mathrm{X} i}$ and the sorption layer coverage $\theta_{\mathrm{s}}$, which is given by the sum of the fractional surface coverage of all competing adsorbate species (i.e. $\mathrm{O}_{3}, \mathrm{H}_{2} \mathrm{O}$, and $\mathrm{NO}_{2}$ ) $\theta_{\mathrm{s}, \mathrm{Xp}}$.

$\alpha_{\mathrm{s}, \mathrm{X} i}=\alpha_{\mathrm{s}, 0, \mathrm{X} i}\left(1-\theta_{\mathrm{s}}\right)=\alpha_{\mathrm{s}, 0, \mathrm{X} i}\left(1-\sum \theta_{\mathrm{s}, \mathrm{X} p}\right)$

$\theta_{\mathrm{s}, \mathrm{X} p}$ is the ratio between the actual and the maximum surface concentration value of $\mathrm{X}_{p}$ : $\theta_{\mathrm{s}, \mathrm{X} p}=\left[\mathrm{X}_{p}\right]_{\mathrm{s}} /\left[\mathrm{X}_{p}\right]_{\mathrm{s}, \max }=\sigma_{\mathrm{s}, \mathrm{X} p}\left[\mathrm{X}_{p}\right]_{\mathrm{s}}$, where $\sigma_{\mathrm{s}, \mathrm{X} p}$ is the effective molecular cross section of $\mathrm{X}_{p}$. In this study, we assume that the effective molecular cross section is the same for all co-adsorbed species unless mentioned otherwise. Accordingly, the inverse molecular cross section can be regarded as the overall concentration of non-interfering sorption sites on the quasi-static surface layer (Pöschl et al., 2007): $[\mathrm{SS}]_{\mathrm{ss}}=\sigma_{\mathrm{s}, \mathrm{X} p}^{-1}$.

The adsorbed molecules can thermally desorb back to the gas phase. Desorption, the inverse of adsorption, can be described by a first-order rate coefficient $k_{\mathrm{d}, \mathrm{X} i}$, which is assumed to be independent on $\theta_{\mathrm{s}, \mathrm{X} i}$. The flux of desorption of gas molecules on the quasi-static particle surface can be expressed as

$J_{\mathrm{des}, \mathrm{X} i}=k_{\mathrm{d}, \mathrm{X} i}\left[\mathrm{X}_{i}\right]_{\mathrm{s}}=\tau_{\mathrm{d}, \mathrm{X} i}^{-1}\left[\mathrm{X}_{i}\right]_{\mathrm{s}}$

The desorption lifetime $\tau_{\mathrm{d}, \mathrm{X} i}$ is the mean residence time on the surface in the absence of surface reaction and surfacebulk transport. Since molecules are desorbed thermally, $k_{\mathrm{d}, \mathrm{X} i}$ depends strongly on temperature. This can be described by an Arrhenius equation as described below.

$k_{\mathrm{d}, \mathrm{X} i}=A \exp \left(\Delta H_{\mathrm{ads}, \mathrm{X} i} / R T\right)$

A pre-exponential factor $A$ is typically $\sim 10^{14} \mathrm{~s}^{-1}$ for chemisorbed species, which is approximately the vibrational 


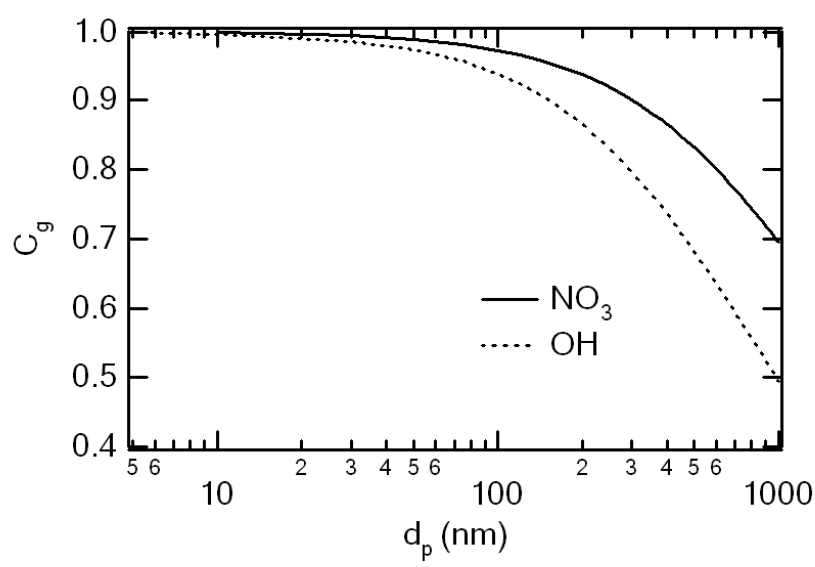

Fig. 2. Gas phase diffusion correction factor $\left(C_{\mathrm{g}}\right)$ for $\mathrm{OH}$ and $\mathrm{NO}_{3}$ plotted against particle diameter $\left(d_{\mathrm{p}}\right)$.

frequency of a molecule bound to the surface. For physisorbed species, $A$ is typically $\sim 10^{12} \mathrm{~s}^{-1}$. Adsorption enthalpy of gaseous $\mathrm{X}_{i}, \Delta H_{\mathrm{ads}, \mathrm{X} i}$ can be estimated roughly by assuming $A$.

The uptake coefficient of gas species $X_{i}$ can be expressed as a ratio between the net fluxes of $X_{i}$ from the gas phase to the condensed phase $J_{\text {net, } \mathrm{X} i}$, and $J_{\mathrm{coll}, \mathrm{X} i}$.

$\gamma_{\mathrm{X} i}=\frac{J_{\mathrm{net}, \mathrm{X} i}}{J_{\mathrm{coll}, \mathrm{X} i}}=\frac{J_{\mathrm{ads}, \mathrm{X} i}-J_{\mathrm{des}, \mathrm{X} i}}{J_{\mathrm{coll}, \mathrm{X} i}}$

\subsection{Surface layer reactions (Langmuir-Hinshelwood- type mechanism)}

The surface layer reactions (SLRs) occur within the surface double layer and involve only adsorbed species or components of the quasi-static layer. In this study the $\mathrm{PAH}_{-} \mathrm{O}_{3}$ system is considered to follow a Langmuir-Hinshelwood-type mechanism, in which ozone first adsorbs to the surface and then reacts with PAH in a quasi-static surface layer (Pöschl et al., 2001; Ammann et al., 2003; Ammann and Pöschl, 2007; Pöschl et al., 2007). Note, however, that traditionally the term "Langmuir-Hinshelwood mechanism" is used for surface catalytic reactions between adsorbed gas species and not to describe reactions that transform the surface (Masel, 1996; IUPAC, 1997). Here we consider three SLRs:

$\mathrm{PAH}(\mathrm{ss})+\mathrm{O}_{3}(\mathrm{~s}) \rightarrow \mathrm{O} 1-\mathrm{PAH}(\mathrm{ss})$

$\mathrm{O}_{3}(\mathrm{~s})+\mathrm{NO}_{2}(\mathrm{~s}) \rightarrow \mathrm{NO}_{3}(\mathrm{~s})$

$\mathrm{PAH}(\mathrm{ss})+\mathrm{NO}_{3}(\mathrm{~s}) \rightarrow \mathrm{O} 2-\mathrm{PAH}(\mathrm{ss})$

The products of SLR1 and SLR3, O1-PAH and O2-PAH, are oxidized non-volatile PAHs. The surface reaction of $\mathrm{O}_{3}$ and $\mathrm{NO}_{2}$ produces the highly reactive $\mathrm{NO}_{3}$ radical, which can react with PAH immediately. The degradation rate of
PAH ( $\left.L_{\text {SLR,PAH }}\right)$ can be described using the second-order rate coefficients $k_{\mathrm{SLR}, \mathrm{PAH}, \mathrm{O} 3}$ and $k_{\mathrm{SLR}, \mathrm{PAH}, \mathrm{NO} 3}$,

$L_{\mathrm{SLR}, \mathrm{PAH}}=k_{\mathrm{SLR}, \mathrm{PAH}, \mathrm{O}_{3}}[\mathrm{PAH}]_{\mathrm{SS}}\left[\mathrm{O}_{3}\right]_{\mathrm{s}}$

$+k_{\mathrm{SLR}, \mathrm{PAH}, \mathrm{NO}_{3}}[\mathrm{PAH}]_{\mathrm{ss}}\left[\mathrm{NO}_{3}\right]_{\mathrm{s}}=k_{\mathrm{s}, \mathrm{PAH}}[\mathrm{PAH}]_{\mathrm{ss}}$

where $k_{\mathrm{S}, \mathrm{PAH}}\left(=k_{\mathrm{SLR}, \mathrm{PAH}, \mathrm{O} 3}\left[\mathrm{O}_{3}\right]_{\mathrm{S}}+k_{\mathrm{SLR}, \mathrm{PAH}, \mathrm{NO} 3}\left[\mathrm{NO}_{3}\right]_{\mathrm{s}}\right)$ is an apparent first-order PAH decay rate coefficient.

The loss rate of ozone by SLR1-SLR2 $\left(L_{\mathrm{SLR}, \mathrm{O}}\right)$ can be described as

$L_{\mathrm{SLR}, \mathrm{O}_{3}}=k_{\mathrm{SLR}, \mathrm{PAH}, \mathrm{O}_{3}}[\mathrm{PAH}]_{\mathrm{ss}}\left[\mathrm{O}_{3}\right]_{\mathrm{s}}$

$+k_{\mathrm{SLR}, \mathrm{O}_{3}, \mathrm{NO}_{2}}\left[\mathrm{O}_{3}\right]_{\mathrm{S}}\left[\mathrm{NO}_{2}\right]_{\mathrm{s}}=k_{\mathrm{s}, \mathrm{O}_{3}}\left[\mathrm{O}_{3}\right]_{\mathrm{s}}$

where $k_{\mathrm{s}, \mathrm{O} 3}\left(=k_{\mathrm{SLR}, \mathrm{PAH}, \mathrm{O} 3}[\mathrm{PAH}]_{\mathrm{ss}}+k_{\mathrm{SLR}, \mathrm{O} 3, \mathrm{NO} 3}\left[\mathrm{NO}_{2}\right]_{\mathrm{s}}\right)$ is an apparent first-order ozone loss rate coefficient.

The production rate of $\mathrm{NO}_{3}$ on the surface, $P_{\mathrm{SLR}, \mathrm{NO} 3}$, can be described as

$P_{\mathrm{SLR}, \mathrm{NO}_{3}}=k_{\mathrm{SLR}, \mathrm{O}_{3}, \mathrm{NO}_{2}}\left[\mathrm{O}_{3}\right]_{\mathrm{s}}\left[\mathrm{NO}_{2}\right]_{\mathrm{s}}$

$-k_{\mathrm{SLR}, \mathrm{PAH}, \mathrm{NO}_{3}}[\mathrm{PAH}]_{\mathrm{ss}}\left[\mathrm{NO}_{3}\right]_{\mathrm{s}}$

\subsection{Gas-surface reaction (Eley-Rideal-type mechanism)}

The gas-surface reaction is a single kinetic step of collision and reaction between gaseous species and surface molecules, which can be regarded as an Eley-Rideal-type mechanism (Ammann and Pöschl, 2007; Pöschl et al., 2007). Note that traditionally the term "Eley-Rideal mechanism" (also named Rideal-Eley or Langmuir-Rideal mechanism) is used for surface catalytic reaction between adsorbed gas species rather than for reactions that transform the surface (Masel, 1996; IUPAC, 1997). Here we consider two GSRs.

$\mathrm{PAH}(\mathrm{ss})+\mathrm{OH}(\mathrm{gs}) \rightarrow \mathrm{O} 3-\mathrm{PAH}(\mathrm{ss})$

$\mathrm{PAH}(\mathrm{ss})+\mathrm{NO}_{3}(\mathrm{gs}) \rightarrow \mathrm{O} 4-\mathrm{PAH}(\mathrm{ss})$

Heterogeneous loss of PAH on the surface $\left(L_{\mathrm{GSR}, \mathrm{PAH}}\right)$ can be described by the following equation (Pöschl et al., 2007).

$L_{\mathrm{GSR}, \mathrm{PAH}}=\sum_{\mathrm{X}_{i}} \gamma_{\mathrm{GSR}, \mathrm{X}_{i}, \mathrm{PAH}} \theta_{\mathrm{ss}, \mathrm{PAH}}\left(1-\theta_{\mathrm{s}}\right) J_{\mathrm{coll}, \mathrm{X}_{i}}$

Here $\gamma_{\mathrm{GSR}, \mathrm{X} i, \mathrm{PAH}}$ is defined as the elementary surface reaction probability that $\mathrm{X}_{i}\left(\mathrm{OH}\right.$ or $\left.\mathrm{NO}_{3}\right)$ undergoes gassurface reaction when colliding with PAH on the surface. $\theta_{\mathrm{ss}, \mathrm{PAH}}$ is the surface coverage of PAH.

\subsection{Steady-state conditions}

The surface mass balance and rate equations can be described as below in summary (Pöschl et al., 2007).

$$
\begin{aligned}
& \mathrm{d}\left[\mathrm{O}_{3}\right]_{\mathrm{s}} / \mathrm{d} t=J_{\mathrm{ads}, \mathrm{O} 3}-J_{\mathrm{des}, \mathrm{O} 3}-L_{\mathrm{SLR}, \mathrm{O} 3} \\
& \mathrm{~d}\left[\mathrm{H}_{2} \mathrm{O}\right]_{\mathrm{s}} / \mathrm{d} t=J_{\mathrm{ads}, \mathrm{H} 2 \mathrm{O}}-J_{\mathrm{des}, \mathrm{H} 2 \mathrm{O}} \\
& \mathrm{d}\left[\mathrm{NO}_{2}\right]_{\mathrm{s}} / \mathrm{d} t=J_{\mathrm{ads}, \mathrm{NO} 2}-J_{\mathrm{des}, \mathrm{NO} 2}-L_{\mathrm{SLR}, \mathrm{NO} 2}
\end{aligned}
$$




$$
\begin{aligned}
& \mathrm{d}[\mathrm{PAH}]_{\mathrm{ss}} / \mathrm{d} t=-L_{\mathrm{SLR}, \mathrm{PAH}}-L_{\mathrm{GSR}, \mathrm{PAH}} \\
& \mathrm{d}\left[\mathrm{NO}_{3}\right]_{\mathrm{s}} / \mathrm{d} t=P_{\mathrm{SLR}, \mathrm{NO} 3}-J_{\mathrm{des}, \mathrm{NO} 3}
\end{aligned}
$$

Steady-state conditions are characterized by $\mathrm{d}\left[\mathrm{X}_{i}\right]_{\mathrm{s}} / \mathrm{d} t=0$ $\left(\mathrm{X}_{i}=\mathrm{O}_{3}, \mathrm{H}_{2} \mathrm{O}\right.$, and $\left.\mathrm{NO}_{2}\right)$. The effective Langmuir adsorption equilibrium constant $K^{\prime}$ ads, $\mathrm{X} i$ can be described as below should be follows.

$$
\begin{aligned}
& K_{\mathrm{ads}, \mathrm{X}_{i}}^{\prime}\left[\mathrm{X}_{i}\right]_{\mathrm{gs}}=\frac{\theta_{\mathrm{s}, \mathrm{X}_{i}}}{1-\theta_{\mathrm{s}}} \\
& K_{\mathrm{ads}, \mathrm{X}_{i}}^{\prime}=\sigma_{\mathrm{s}, \mathrm{X}_{i}} \frac{k_{\mathrm{a}, 0, \mathrm{X}_{i}}}{k_{\mathrm{d}, \mathrm{X}_{i}}+k_{\mathrm{s}, \mathrm{X}_{i}}}
\end{aligned}
$$

If surface reactions are much slower than desorption $\left(k_{\mathrm{d}, \mathrm{X} i} \gg k_{\mathrm{s}, \mathrm{X} i}\right)$, then $K^{\prime}{ }_{\mathrm{ads}, \mathrm{X} i}$ is equal to a Langmuir adsorption equilibrium constant $K_{\mathrm{ads}, \mathrm{X} i}\left(=\sigma_{\mathrm{s}, \mathrm{X} i} k_{\mathrm{a}, 0, \mathrm{X} i} / k_{\mathrm{d}, \mathrm{X} i}\right)$. Under these conditions the desorption lifetime $\tau_{\mathrm{d}, \mathrm{X} i}$ and firstorder rate coefficient $k_{\mathrm{d}, \mathrm{X} i}$ are given by

$k_{\mathrm{d}, \mathrm{X}_{i}}=\frac{1}{\tau_{\mathrm{d}, \mathrm{X}_{i}}} \approx \sigma_{\mathrm{s}, \mathrm{X}_{i}} \frac{k_{\mathrm{a}, 0, \mathrm{X}_{i}}}{K_{\mathrm{ads}, \mathrm{X}_{i}}^{\prime}}=\frac{\alpha_{\mathrm{s}, 0, \mathrm{X}_{i}} \omega_{\mathrm{X}_{i}} \sigma_{\mathrm{s}, \mathrm{X}_{i}}}{4 K_{\mathrm{ads}, \mathrm{X}_{i}}^{\prime}}$

The surface concentration of $\mathrm{X}_{i}$ can be expressed as

$\left[\mathrm{X}_{i}\right]_{\mathrm{s}}=\sigma_{\mathrm{s}, \mathrm{X}_{i}}^{-1} \theta_{\mathrm{s}, \mathrm{X}_{i}}=\sigma_{\mathrm{s}, \mathrm{X}_{i}}^{-1} \frac{K_{\mathrm{ads}, \mathrm{X}_{i}}^{\prime}\left[\mathrm{X}_{i}\right]_{\mathrm{gs}}}{1+\sum K_{\mathrm{ads}, \mathrm{X}_{i}}\left[\mathrm{X}_{i}\right]_{\mathrm{gs}}}$

An apparent first order rate coefficient $k_{\mathrm{S}, \mathrm{PAH}}$ can be described as

$k_{\mathrm{s}, \mathrm{PAH}}=k_{\mathrm{s}, \mathrm{PAH}, \max } \frac{K_{\mathrm{ads}, \mathrm{X}_{i}}^{\prime}\left[\mathrm{X}_{i}\right]_{\mathrm{gs}}}{1+\sum_{p} K^{\prime}{ }_{\mathrm{ads}, \mathrm{X}_{p}}\left[\mathrm{X}_{p}\right]_{\mathrm{gs}}}$

where $k_{\mathrm{S}, \mathrm{PAH} \text {,max }}$ is a maximum pseudo-first order rate coefficient of PAH.

The uptake coefficient of ozone $\left(\gamma_{\mathrm{O} 3}\right)$ can be calculated as

$\gamma_{\mathrm{O}_{3}}=\frac{L_{\mathrm{SLR}, \mathrm{O}_{3}}}{J_{\mathrm{coll}, \mathrm{O}_{3}}}=\frac{4 k_{\mathrm{s}, \mathrm{PAH}}}{\sigma_{\mathrm{PAH}} \omega_{\mathrm{O}_{3}}\left[\mathrm{O}_{3}\right]_{\mathrm{gs}}}$

The initial concentration of PAH is considered to be the inverse of the effective molecular cross section $\sigma_{\mathrm{PAH}}$ and is estimated assuming one aromatic ring has $0.2 \mathrm{~nm}^{2}$. For example, $\sigma_{\mathrm{BaP}}$ is assumed to be $1 \mathrm{~nm}^{2}$ because $\mathrm{BaP}$ consists of five aromatic rings (Pöschl et al., 2001).

\section{Experimental data analysis and steady-state conditions}

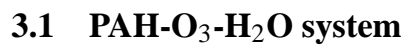

The kinetics of the heterogeneous reaction between gaseous ozone and PAHs bound on various substrates have been investigated in several laboratory studies (Wu et al., 1984; Alebic-Juretic et al., 1990; Pöschl et al., 2001; Ammann et al., 2003; Mmereki and Donaldson, 2003; Kwamena et al.,

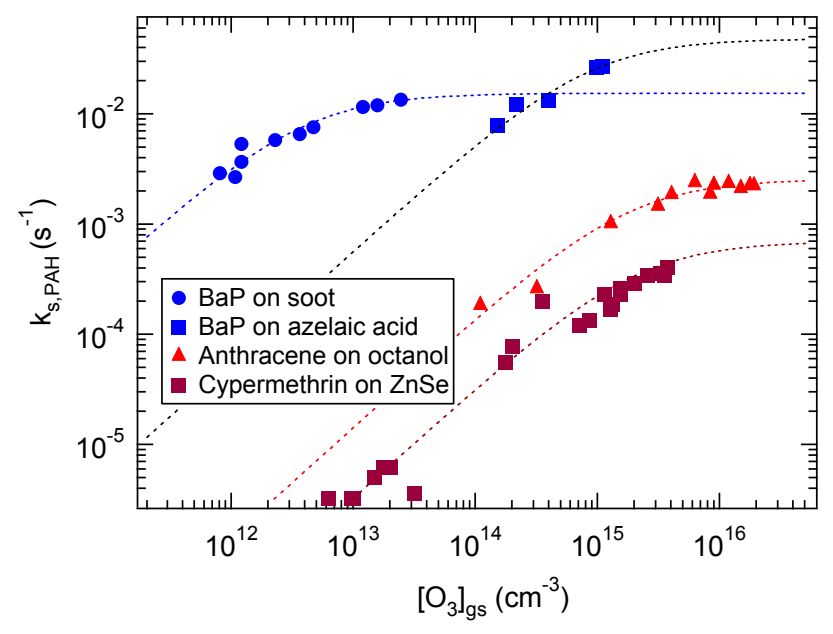

Fig. 3. Pseudo-first-order PAH decay rate coefficients $\left(k_{\mathrm{s}, \mathrm{PAH}}\right)$ as a function of gas phase ozone concentration $\left(\left[\mathrm{O}_{3}\right]_{\mathrm{gs}}\right)$ under dry conditions: $\mathrm{BaP}$ on soot aerosol (Pöschl et al., 2001), BaP on azelaic acid aerosol (Kwamena et al., 2004), Anthracene on octanol (Kahan et al., 2006), and cypermethrin on ZnSe (Segal-Rosenheimer and Dubowski, 2008).

2004; Mmereki et al., 2004; Donaldson et al., 2005; Kahan et al., 2006; Kwamena et al., 2006, 2007). The investigated PAHs comprise benzo[a]pyrene (BaP), anthracene, naphthalene, pyrene, phenanthrene, benzo[a]anthracene (BaA), perylene, and fluoranthene. The substrates include soot, azelaic acid, phenylsiloxane, glass, $\mathrm{ZnSe}$, non-activated silica gel, fused silica, octanol, decanol, stearic acid, octanoic acid, and hexanoic acid and water. As specified in Table 1, the PAHs were deposited on aerosol particles, solid or liquid substrates, or on organic thin films on water. Self-assembled monolayers (SAM) of alkenes and cypermethrin were also analyzed for comparison (Dubowski et al., 2004; SegalRosenheimer and Dubowski, 2008), as they follow similar reaction mechanisms and kinetics.

\subsubsection{Basic physicochemical parameters}

As illustrated in Fig. 3, the pseudo-first order PAH decay rate coefficients $\left(k_{\mathrm{s}, \mathrm{PAH}}\right)$ typically exhibit a nonlinear dependence on gas phase ozone concentration, which is consistent with a Langmuir-Hinshelwood-type mechanism. In contrast, an Eley-Rideal-type mechanism would lead to a linear dependence of $k_{\mathrm{s} \text {, PAH }}$ on gas phase ozone concentration. In the $\mathrm{PAH}-\mathrm{O}_{3}-\mathrm{H}_{2} \mathrm{O}$ system Eq. (23) can be simplified to

$k_{\mathrm{s}, \mathrm{PAH}}$

$=\frac{k_{\mathrm{s}, \mathrm{PAH}, \max } K^{\prime}{ }_{\text {ads, } \mathrm{O}_{3}}\left[\mathrm{O}_{3}\right]_{\mathrm{gs}}}{1+K^{\prime}{ }_{\text {ads }, \mathrm{O}_{3}}\left[\mathrm{O}_{3}\right]_{\mathrm{gs}}+K^{\prime}{ }_{\text {ads }, \mathrm{H}_{2} \mathrm{O}}\left[\mathrm{H}_{2} \mathrm{O}\right]_{\mathrm{gs}}}$

The parameters of $k_{\mathrm{s}, \mathrm{PAH} \text {,max }}$ and $K^{\prime}$ ads,O3 were obtained by a non-linear least-squares fit of Eq. (25) to the experimental data pairs of $k_{\mathrm{s}, \mathrm{PAH}}$ and $\left[\mathrm{O}_{3}\right]_{\mathrm{gs}}$ for each $\mathrm{PAH}$ and substrate 
Table 1. Basic physicochemical parameters of $\mathrm{O}_{3}$ in the $\mathrm{PAH}-\mathrm{O}_{3}-\mathrm{H}_{2} \mathrm{O}$ system with different PAHs and substrates. The upper part is kinetics data of PAHs on solid substrates, the middle part is that of PAHs on liquid substrates, and the bottom part is that of non-PAH.

\begin{tabular}{|c|c|c|c|c|c|c|c|c|c|}
\hline PAH & Substrate & $\begin{array}{l}\text { RH } \\
(\%)\end{array}$ & $\begin{array}{c}K_{\text {ads, }} \mathrm{O} 3 \\
\left(10^{-15} \mathrm{~cm}^{3}\right)\end{array}$ & $\begin{array}{c}k_{\mathrm{s}, \mathrm{PAH}, \max } \\
\left(\mathrm{s}^{-1}\right)\end{array}$ & $\begin{array}{c}k_{\mathrm{SLR}, \mathrm{PAH}, \mathrm{O} 3} \\
\left(10^{-17} \mathrm{~cm}^{2} \mathrm{~s}^{-1}\right)\end{array}$ & $\begin{array}{l}k_{\mathrm{d}, \mathrm{O} 3} \\
\left(\mathrm{~s}^{-1}\right)\end{array}$ & $\begin{array}{c}\tau_{\mathrm{d}, \mathrm{O} 3} \\
(\mathrm{~s})\end{array}$ & $\begin{array}{c}\Delta H_{\text {ads, } \mathrm{O} 3} \\
\left(\mathrm{~kJ} \mathrm{~mol}^{-1}\right)\end{array}$ & Reference \\
\hline $\mathrm{BaP}$ & soot aerosol & 25 & 255 & 0.0155 & 3.37 & 0.08 & 13.0 & -86 & Pöschl et al. (2001) \\
\hline $\mathrm{BaP}$ & azelaic acid aerosol & 72 & 4.39 & 0.0600 & 10.4 & 3.56 & 0.28 & -76 & Kwamena et al. (2004) \\
\hline $\mathrm{BaP}$ & soot aerosol & 0 & 255 & 0.0154 & 2.66 & 0.06 & 16.3 & -86 & Pöschl et al. (2001) \\
\hline $\mathrm{BaP}$ & azelaic acid aerosol & 0 & 1.18 & 0.0480 & 8.30 & 13.2 & 0.08 & -73 & Kwamena et al. (2004) \\
\hline $\mathrm{BaP}$ & $\mathrm{NaCl}$ aerosol & 0 & 0.12 & 0.0320 & 5.54 & 130 & 0.01 & -67 & Kwamena et al. (2004) \\
\hline $\mathrm{BaP}$ & fused silica & 0 & 27.1 & 0.0325 & 5.62 & 0.58 & 1.74 & -81 & Wu et al. (1984) \\
\hline $\mathrm{BaP}$ & silica gel & 0 & 9.4 & 0.0325 & 5.62 & 1.67 & 0.60 & -78 & Alebic-Juretic et al. (1990) \\
\hline Anthracene & glass & 0 & 2.85 & 0.0060 & 1.04 & 5.48 & 0.18 & -75 & Kwamena et al. (2006) \\
\hline Anthracene & azelaic acid aerosol & 0 & 2.24 & 0.0550 & 9.52 & 6.97 & 0.14 & -75 & Kwamena et al. (2007) \\
\hline $\mathrm{BaA}$ & silica gel & 0 & 38.6 & 0.004 & 0.69 & 0.40 & 2.47 & -82 & Alebic-Juretic et al. (1990) \\
\hline Pyrene & silica gel & 0 & 86.0 & 0.001 & 0.17 & 0.18 & 5.51 & -84 & Alebic-Juretic et al. (1990) \\
\hline Perylene & silica gel & 0 & 67.9 & 0.004 & 0.69 & 0.23 & 4.35 & -83 & Alebic-Juretic et al. (1990) \\
\hline Perylene & fused silica & 0 & 4.4 & 0.004 & 0.69 & 3.55 & 0.28 & -76 & Wu et al. (1984) \\
\hline Fluoranthene & silica gel & 0 & 65.0 & 0.0001 & 0.02 & 0.24 & 4.17 & -83 & Alebic-Juretic et al. (1990) \\
\hline $\mathrm{BaP}$ & octanol & 0 & 0.35 & 0.0055 & 0.94 & 45.0 & 0.02 & -70 & Kahan et al. (2006) \\
\hline Anthracene & phenylsiloxane oil aerosol & 0 & 104 & 0.0100 & 1.73 & 0.15 & 6.66 & -84 & Kwamena et al. (2007) \\
\hline Anthracene & octanol/decanol & 0 & 0.56 & 0.0026 & 0.44 & 28.0 & 0.04 & -71 & Kahan et al. (2006) \\
\hline Anthracene & octanol on water & 0 & 1.83 & 0.0026 & 0.45 & 8.53 & 0.12 & -74 & Mmereki and Donaldson (2003) \\
\hline Anthracene & water & 0 & 0.45 & 0.0026 & 0.45 & 34.7 & 0.03 & -71 & Mmereki and Donaldson (2003) \\
\hline Anthracene & stearic acid on water & 0 & 0.47 & 0.0024 & 0.41 & 33.4 & 0.03 & -71 & Mmereki et al. (2004) \\
\hline Anthracene & octanoic acid on water & 0 & 0.94 & 0.0013 & 0.22 & 16.7 & 0.06 & -72 & Mmereki et al. (2004) \\
\hline Anthracene & hexanoic acid on water & 0 & 1.2 & 0.0004 & 0.07 & 13.0 & 0.08 & -73 & Mmereki et al. (2004) \\
\hline Naphthalene & octanol & 0 & 0.97 & 0.0009 & 0.15 & 16.1 & 0.06 & -72 & Kahan et al. (2006) \\
\hline Pyrene & octanol & 0 & 0.32 & 0.0007 & 0.12 & 48.8 & 0.02 & -70 & Kahan et al. (2006) \\
\hline Pyrene & water & 0 & 0.86 & 0.0012 & 0.20 & 18.2 & 0.06 & -72 & Donaldson et al. (2005) \\
\hline Pyrene & octanol on water & 0 & 1.66 & 0.0015 & 0.26 & 9.41 & 0.11 & -74 & Donaldson et al. (2005) \\
\hline Phenanthrene & octanol & 0 & 0.16 & 0.0006 & 0.10 & 97.6 & 0.01 & -68 & Kahan et al. (2006) \\
\hline SAM C3\&C8 & $\mathrm{ZnSe}$ & 0 & 25 & 0.0060 & 1.04 & 0.62 & 1.60 & -80 & Dubowski et al. (2004) \\
\hline Cypermethrin & $\mathrm{ZnSe}$ & 0 & 0.47 & 0.0007 & 0.12 & 33.2 & 0.03 & -71 & $\begin{array}{l}\text { Segal-Rosenheimer and } \\
\text { Dubowski (2007) }\end{array}$ \\
\hline
\end{tabular}

(IGOR software). The experimental data were taken from the referenced studies, and the fit results are summarized in Table 1 .

Pöschl et al. (2001) also measured the surface concentration of ozone, $\left[\mathrm{O}_{3}\right]_{\mathrm{s}}$, as a function of gas phase ozone concentration, which can be described by the following equation:

$\left[\mathrm{O}_{3}\right]_{\mathrm{s}}=\frac{\sigma_{\mathrm{s}, \mathrm{X}_{i}}^{-1} K^{\prime}{ }_{\mathrm{ads}, \mathrm{O}_{3}}\left[\mathrm{O}_{3}\right]_{\mathrm{gs}}}{1+K_{\mathrm{ads}, \mathrm{O}_{3}}^{\prime}\left[\mathrm{O}_{3}\right]_{\mathrm{gs}}+K^{\prime}{ }_{\mathrm{ads}, \mathrm{H}_{2} \mathrm{O}}\left[\mathrm{H}_{2} \mathrm{O}\right]_{\mathrm{gs}}}$

A non-linear least squares fit yielded $\sigma_{\mathrm{s}, \mathrm{O} 3}=0.17 \mathrm{~nm}^{2}$ $\left([S S]_{s s}=5.8 \times 10^{14} \mathrm{~cm}^{-2}\right)$. We assumed this value for the other studies as well, because Pöschl et al. (2001) is the only study that reported $\left[\mathrm{O}_{3}\right]_{\mathrm{s}}$. Second-order rate coefficients $\left(k_{\mathrm{SLR}, \mathrm{PAH}, \mathrm{O} 3}\right)$ were calculated using the relation $k_{\mathrm{S}, \mathrm{PAH}, \text { max }}=k_{\mathrm{SLR}, \mathrm{PAH}, \mathrm{O} 3} \sigma_{\mathrm{s}, \mathrm{O} 3}^{-1}$. Ozone desorption lifetimes $\left(\tau_{\mathrm{d}, \mathrm{O} 3}\right)$ and the corresponding desorption rate coefficients $\left(k_{\mathrm{d}, \mathrm{O} 3}\right)$ were estimated using Eq. $(21)$, assuming a surface accommodation coefficient of $\alpha_{\mathrm{s}, 0, \mathrm{O} 3}=1.0 \times 10^{-3}$ (Rogaski et al., 1997) for the adsorbate-free surface.

The obtained $\tau_{\mathrm{d}, \mathrm{O} 3}$ values are in the range of $10 \mathrm{~ms}-10 \mathrm{~s}$ depending on the substrate (Table 1). The relatively long desorption lifetimes suggest chemisorption of $\mathrm{O}_{3}^{-}$possibly in the form of $\mathrm{O}$ atoms. Thus, the $\tau_{\mathrm{d}, \mathrm{O} 3}$ values should be regarded as apparent desorption lifetimes that may effectively include the dissociation of ozone or other intermediate steps of chemical interaction at the surface as will be discussed below.

From $k_{\mathrm{d}, \mathrm{O} 3}=\tau_{\mathrm{d}, \mathrm{O} 3}^{-1}$ approximate adsorption enthalpies $\Delta H_{\text {ads, } \mathrm{O} 3}$ were estimated using Eq. (8) and assuming a preexponential factor of $A=10^{14} \mathrm{~s}^{-1}$ (Pöschl et al., 2001). Test calculations with $A=10^{12}-10^{15} \mathrm{~s}^{-1}$ gave an uncertainty range of $\pm 6 \mathrm{~kJ} \mathrm{~mol}^{-1}$ in $\Delta H_{\mathrm{ads}, \mathrm{O} 3 .} K^{\prime}{ }_{\text {ads, } \mathrm{O} 3}$ is approximated to $K_{\mathrm{ads}, \mathrm{O} 3}$, as $k_{\mathrm{d}, \mathrm{O} 3}$ is one to three orders of magnitude larger than $k_{\mathrm{s}, \mathrm{O} 3}$. The $K_{\mathrm{ads}, \mathrm{O} 3}$ values are one to three orders of magnitude larger for solid substrates compared to liquid substrates. This corresponds to longer desorption lifetimes and larger negative adsorption enthalpy values for solid substrates $\left(\Delta H_{\mathrm{ads}, \mathrm{O} 3} \approx-(70-90) \mathrm{kJ} \mathrm{mol}^{-1}\right)$. Additionally, $k_{\mathrm{S}, \mathrm{PAH} \text {,max }}$ and $k_{\mathrm{SLR}, \mathrm{PAH}, \mathrm{O} 3}$ are by an order of magnitude larger on solid substrates. Self-assembled monolayers of alkenes show similar adsorption and reaction rate coefficients as PAHs on solid substrates, whereas the parameters for cypermethrin are similar to PAHs on liquid substrates.

Most studies were performed under dry conditions (RH $\approx 0 \%)$, but Pöschl et al. (2001) and Kwamena et al. (2004) also reported results for humid conditions. The

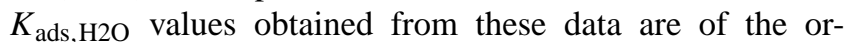
der of $10^{-17} \mathrm{~cm}^{-3}$ (Table 2), i.e., 2-4 orders of magnitude smaller than $K_{\text {ads, } \mathrm{O} 3}$. Assuming $\alpha_{\mathrm{s}, 0, \mathrm{H} 2 \mathrm{O}}=6.0 \times 10^{-4}$ 
Table 2. Basic physicochemical parameters of $\mathrm{H}_{2} \mathrm{O}$ in the $\mathrm{BaP}-\mathrm{O}_{3}-\mathrm{NO}_{2}-\mathrm{H}_{2} \mathrm{O}$ system on soot and azelaic acid.

\begin{tabular}{|c|c|c|c|c|c|c|c|c|c|}
\hline Substrate & $\begin{array}{l}\mathrm{RH} \\
(\%)\end{array}$ & $\begin{array}{l}\mathrm{NO}_{2} \\
(\mathrm{ppb})\end{array}$ & $\begin{array}{c}K_{\mathrm{ads}, \mathrm{H} 2 \mathrm{O}} \\
\left(10^{-17} \mathrm{~cm}^{3}\right)\end{array}$ & $\begin{array}{c}{[\mathrm{SS}]_{\mathrm{ss}}} \\
\left(10^{14} \mathrm{~cm}^{-2}\right)\end{array}$ & $\begin{array}{c}\tau_{\mathrm{d}, \mathrm{H} 2 \mathrm{O}} \\
(\mathrm{s})\end{array}$ & $\begin{array}{c}k_{\mathrm{d}, \mathrm{H} 2 \mathrm{O}} \\
\left(\mathrm{s}^{-1}\right)\end{array}$ & $\begin{array}{l}\Delta H_{\mathrm{ads}, \mathrm{H} 2 \mathrm{O}} \\
\left(\mathrm{kJ} \mathrm{mol}^{-1}\right)\end{array}$ & Reference & Data set \\
\hline soot & 25 & 0 & 0.17 & 4.60 & $1.33 \times 10^{-4}$ & $7.54 \times 10^{3}$ & $-35 \pm 9$ & Pöschl et al. (2001) & {$\left[\mathrm{O}_{3}\right]_{\mathrm{s}}$ vs. $\left[\mathrm{O}_{3}\right]_{\mathrm{gs}}$} \\
\hline soot & 25 & 1000 & 0.15 & 2.24 & $5.69 \times 10^{-5}$ & $1.76 \times 10^{4}$ & $-33 \pm 9$ & Schauer (2004) & {$\left[\mathrm{O}_{3}\right]_{\mathrm{s}}$ vs. $\left[\mathrm{O}_{3}\right]_{\mathrm{gs}}$} \\
\hline soot & 25 & 0 & 1.02 & - & $7.95 \times 10^{-4}$ & $1.26 \times 10^{3}$ & $-39 \pm 9$ & Pöschl et al. (2001) & $k_{\mathrm{s}, \mathrm{BaP}}$ vs. $\left[\mathrm{O}_{3}\right]_{\mathrm{gs}}$ \\
\hline soot & 25 & 1000 & 1.18 & _- & $4.48 \times 10^{-4}$ & $2.23 \times 10^{3}$ & $-38 \pm 9$ & Schauer (2004) & $k_{\mathrm{S} B \mathrm{BP}}$ vs. $\left[\mathrm{O}_{3}\right]_{\mathrm{gs}}$ \\
\hline azelaic acid & 72 & 0 & 0.10 & - & $9.80 \times 10^{-5}$ & $1.02 \times 10^{4}$ & $-34 \pm 9$ & Kwamena et al. (2004) & $k_{\mathrm{s}, \mathrm{BaP}}$ vs. $\left[\mathrm{O}_{3}\right]_{\mathrm{gs}}$ \\
\hline
\end{tabular}

(Rogaski et al., 1997) we obtained $\mathrm{H}_{2} \mathrm{O}$ desorption lifetimes of the order of $0.1 \mathrm{~ms}$, indicating physisorption of

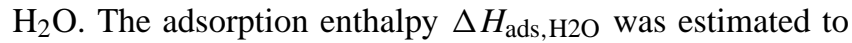
be $-36( \pm 9) \mathrm{kJ} \mathrm{mol}^{-1}$ assuming a pre-exponential factor in the range of $10^{8}-10^{12} \mathrm{~s}^{-1}$ (Pöschl et al., 2001).

Kwamena et al. (2007) pointed out that the substrate influences the partitioning of ozone to the surface irrespective of the PAH adsorbed to it. They also suggested that different experimental approaches can yield different results. In particular, they found that PAHs may dissolve into the substrate of thin film experiments, thereby affecting the reaction kinetics and partitioning of $\mathrm{O}_{3}$ as will be discussed below.

According to molecular dynamics (MD) simulations the desorption lifetime of ozone on at the interface of pure water and air should be only 36 ps (Vieceli et al., 2005) which is much shorter than the values listed in Table 1. Possible explanations for the differences are: (1) The surfaces considered in our study are covered by PAH molecules and thus likely to interact differently with ozone. (2) The desorption lifetimes calculated from measurement-derived adsorption constants depend inversely on the assumed surface accommodation coefficients $\left(\alpha_{\mathrm{s}, 0}\right)$ and might thus be up to three orders of magnitude shorter if $\alpha_{\mathrm{s}, 0}$ were close to unity. (3) The chemical species actually residing at the surface might be $\mathrm{O}$ atoms rather than ozone molecules, and thus additional processes such as a dissociation reaction or other intermediate steps of chemical interactions at the surface might have to be considered for full mechanistic understanding. (4) Surface-bulk exchange as well as mass transport and chemical reactions might also play a role for liquid substrates. Further investigations will be needed to resolve these issues, and we are planning to pursue such investigations using K2-SURF as well as kinetic double- and multi-layer models that resolves also diffusion and reaction in the bulk of the particle or substrate, respectively (K2-SUB, Pfrang et al., 2009; KM-SUB, Shiraiwa et al., 2009).

\subsubsection{Uptake of ozone}

Ozone uptake coefficients for the $\mathrm{PAH}-\mathrm{O}_{3}-\mathrm{H}_{2} \mathrm{O}$ system were calculated using Eq. (24) and are shown in Fig. 4. The $\gamma_{\mathrm{O} 3}$ values exhibt a strong dependence on the gas phase concentration of ozone $\left(\left[\mathrm{O}_{3}\right]_{\mathrm{gs}} \approx 10^{11}-10^{16} \mathrm{~cm}^{-3}\right.$ corresponding to $10-10^{6} \mathrm{ppb}$ under dry standard conditions at $1013 \mathrm{hPa}$ and $298 \mathrm{~K}$ ). The symbols represent literature data (Table 1), and the curves represent three characteristic K2-SURF model scenarios: (1) a soot surface with $\tau_{\mathrm{d}, \mathrm{O} 3}=10 \mathrm{~s}$ and $k_{\mathrm{SLR}, \mathrm{PAH}, \mathrm{O} 3}=2.7 \times 10^{-17}$ (red solid line); (2) a solid organic surface with $\tau_{\mathrm{d}, \mathrm{O} 3}=1 \mathrm{~s}$ and $k_{\mathrm{SLR}, \mathrm{PAH}, \mathrm{O} 3}=2.7 \times 10^{-17}$ (red dotted line); (3) a liquid organic surface with $\tau_{\mathrm{d}, \mathrm{O} 3}=0.1 \mathrm{~s}$ and $k_{\text {SLR,PAH,O3 }}=5.0 \times 10^{-18}$ (black solid line).

Systems on a solid substrate such as soot, glass and solid organic substrate are well described by the red lines in Fig. 4, covering over five orders of magnitude in both $\gamma_{\mathrm{O} 3}$ and $\left[\mathrm{O}_{3}\right]_{\mathrm{gs}}$. Most experimental data were obtained at high $\left[\mathrm{O}_{3}\right]_{\mathrm{gs}}$, but along the model lines $\gamma_{\mathrm{O} 3}$ can be extrapolated to atmospheric conditions $\left(\left[\mathrm{O}_{3}\right]_{\mathrm{gs}}<150 \mathrm{ppb}\right)$. There $\gamma_{\mathrm{O} 3}$ is estimated to be $\sim 10^{-5}$ for PAHs on a soot surface and $\sim 10^{-6}$ on a solid organic surface.

On liquid substrates $\gamma_{\mathrm{O} 3}$ is substantially lower $\left(\approx 10^{-8}\right)$. A possible explanation is that some $\mathrm{PAH}$ may be dissolved in the liquid substrate (Kwamena et al., 2007), leading to a reduction of the actual PAH concentration on the surface and to a decrease of $\gamma_{\mathrm{O} 3}$ according to Eq. (24). Transport of PAH from the quasi-static layer to the bulk can be modelled by surface-bulk exchange fluxes $\left(J_{\mathrm{ss}, \mathrm{b}}, J_{\mathrm{b}, \mathrm{ss}}\right)$ which goes beyond the present study. Still, these data are well fitted by the black solid line suggesting $\gamma_{\mathrm{O} 3}$ values of the order of $10^{-8}$ under atmospheric conditions.

McCabe and Abbatt (2009) have already pointed out a remarkable similarity of $\gamma_{\mathrm{O} 3}$ on a variety of surfaces (soot, 1hexadecene, metal oxides, atmospheric mineral dust, PAHs coated to soot, organic, and water substrates) both in their absolute magnitude and in their partial pressure dependence, especially given the very different experimental techniques (Knudsen cells, aerosol flow tubes, etc.). Possible explanations and rate limiting steps discussed in their and earlier studies are: surface diffusion of adsorbed ozone molecules (Kwamena et al., 2007) and/or multiple steps of chemical reaction involving possible intermediates like $\mathrm{O}_{3}^{-}$ions (Nelander and Nord, 1979) or O atoms (Stephens et al., 1986; Pöschl et al., 2001; Sullivan et al., 2004). 


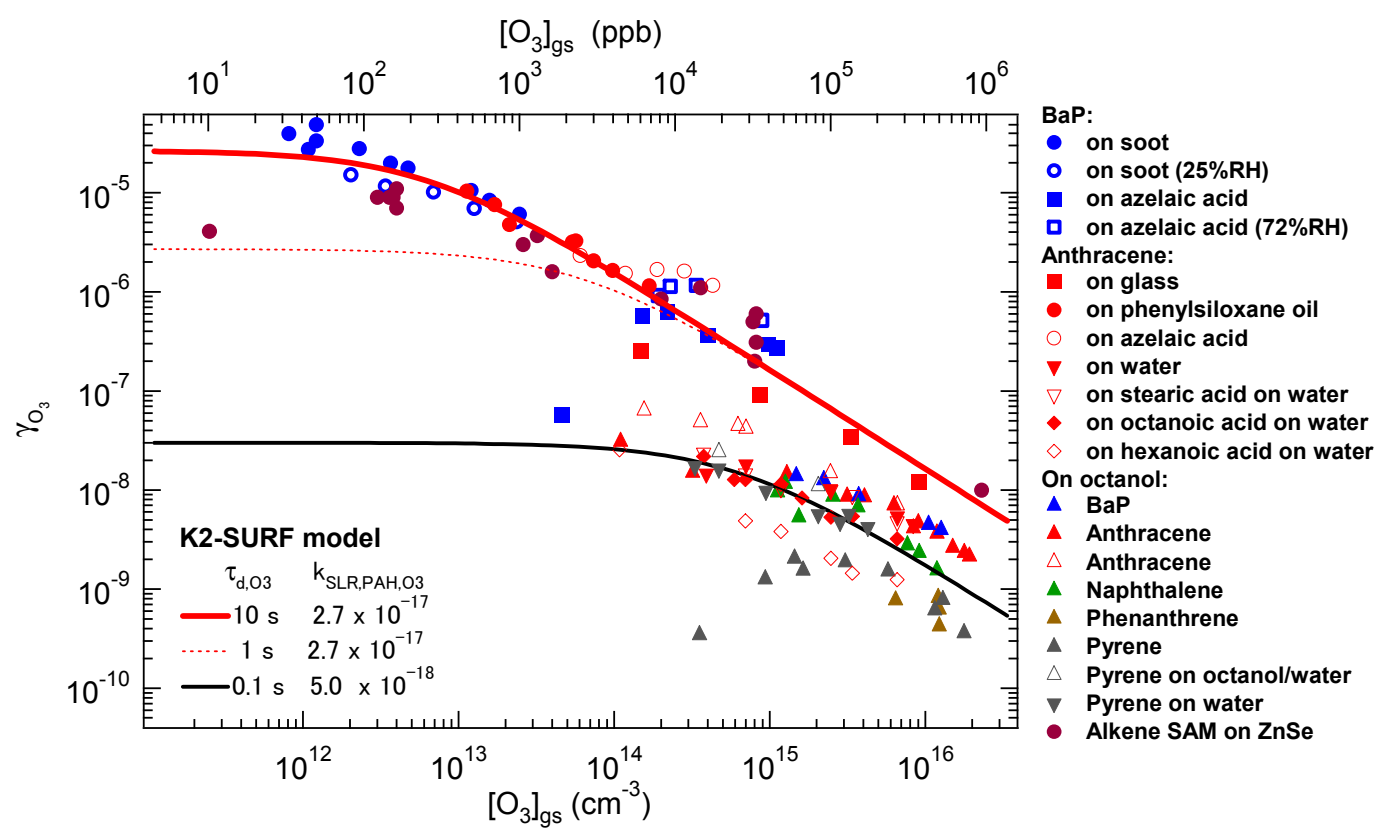

Fig. 4. Ozone uptake coefficients $\left(\gamma_{\mathrm{O} 3}\right)$ for different PAHs and substrates. Symbols represent literature data (Table 1). Lines show model results assuming the following parameters: (1) $\tau_{\mathrm{d}, \mathrm{O} 3}=10 \mathrm{~s}$ and $k_{\mathrm{SLR}, \mathrm{PAH}, \mathrm{O} 3}=2.7 \times 10^{-17}$ for soot surfaces (red solid line), (2) $\tau_{\mathrm{d}, \mathrm{O} 3}=1 \mathrm{~s}$ and $k_{\mathrm{SLR}, \mathrm{PAH}, \mathrm{O} 3}=2.7 \times 10^{-17}$ for solid organic surfaces (red dotted line), (3) $\tau_{\mathrm{d}, \mathrm{O} 3}=0.1 \mathrm{~s}$ and $k_{\mathrm{SLR}, \mathrm{PAH}, \mathrm{O} 3}=5.0 \times 10^{-18}$ for liquid surfaces (black solid line).

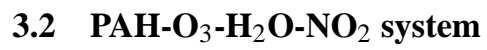

The oxidation of the PAH benzo[a]pyrene upon interaction with $\mathrm{O}_{3}, \mathrm{H}_{2} \mathrm{O}$ and $\mathrm{NO}_{2}$ was investigated using data from Schauer (2004). As illustrated in Fig. 5, the pseudo-first order PAH decay rate coefficients $\left(k_{\mathrm{s}, \mathrm{PAH}}\right)$ exhibit a nonlinear dependence on gas phase ozone concentration, which is consistent with a Langmuir-Hinshelwood-type reaction mechanism and can be described by the following equations.

$\left[\mathrm{O}_{3}\right]_{\mathrm{s}}$

$=\frac{\sigma_{\mathrm{s}, \mathrm{O}_{3}}^{-1} K^{\prime}{ }_{\text {ads }, \mathrm{O}_{3}}\left[\mathrm{O}_{3}\right]_{\mathrm{gs}}}{1+K^{\prime}{ }_{\mathrm{ads}, \mathrm{O}_{3}}\left[\mathrm{O}_{3}\right]_{\mathrm{gs}}+K^{\prime}{ }_{\mathrm{ads}, \mathrm{H}_{2} \mathrm{O}}\left[\mathrm{H}_{2} \mathrm{O}\right]_{\mathrm{gs}}+K^{\prime}{ }_{\text {ads }, \mathrm{NO}_{2}}\left[\mathrm{NO}_{2}\right]_{\mathrm{gs}}}$

$k_{\mathrm{s}, \mathrm{PAH}}$

$=\frac{k_{\mathrm{s}, \mathrm{PAH}, \max } K_{\mathrm{ads}, \mathrm{O}_{3}}^{\prime}\left[\mathrm{O}_{3}\right]_{\mathrm{gs}}}{1+K^{\prime}{ }_{\text {ads }, \mathrm{O}_{3}}\left[\mathrm{O}_{3}\right]_{\mathrm{gs}}+K^{\prime}{ }_{\mathrm{ads}, \mathrm{H}_{2} \mathrm{O}}\left[\mathrm{H}_{2} \mathrm{O}\right]_{\mathrm{gs}}+K^{\prime}{ }_{\text {ads, } \mathrm{NO}_{2}}\left[\mathrm{NO}_{2}\right]_{\mathrm{gs}}}$

Non-linear least squares fits yielded the effective $\mathrm{NO}_{2}$ adsorption constants summarized in Table 3 (assuming $K_{\text {ads,NO2 }} \approx K^{\prime}$ ads, NO2 $)$. They are of the order of $10^{-14} \mathrm{~cm}^{3}$, which is similar to the ozone adsorption constants. Assuming $\alpha_{\mathrm{s}, 0, \mathrm{NO} 2}=0.064$ (Tabor et al., 1994) we obtained $\mathrm{NO}_{2}$ desorption lifetime estimates of about $\tau_{\mathrm{d}, \mathrm{NO} 2} \approx 50 \mathrm{~ms}$, indicating chemisorption of $\mathrm{NO}_{2}$. The adsorption enthalpy
$\Delta H_{\text {ads, NO2 }}$ was estimated to be $-67( \pm 6) \mathrm{kJ} \mathrm{mol}^{-1}$ assuming a range of pre-exponential factors $\left(A \approx 10^{12}-10^{14} \mathrm{~s}^{-1}\right)$.

Table 4 shows the basic physicochemical parameters of $\mathrm{O}_{3}$ in this system. The apparent overall concentration of sorption sites $[\mathrm{SS}]_{\mathrm{ss}}$ decreases systematically as the $\mathrm{NO}_{2}$ concentration increases, which implies that the effective molecular cross section of adsorbed ozone is smaller than that of $\mathrm{NO}_{2}$. This finding suggests that ozone may indeed be adsorbed in the form of $\mathrm{O}$ atoms, because molecular $\mathrm{O}_{3}$ is not expected to be smaller than $\mathrm{NO}_{2}$. Alternatively or in addition, other intermediates might also be involved in the coadsorption of $\mathrm{O}_{3}$ and $\mathrm{NO}_{2}$ (e.g., $\mathrm{NO}_{3}$ or $\mathrm{N}_{2} \mathrm{O}_{5}$ formed by reaction of $\mathrm{NO}_{2}$ with $\mathrm{O}_{3}$ or $\mathrm{O}$ ). Further investigations will be needed to elucidate the actual mechanism of interaction between different co-adsorbed species, and additional processes could be flexibly included in K2-SURF. Nevertheless, the simple Langmuir-Hinshelwood-type formalisms applied in this study appear to sufficient for efficient description of multi-component systems as illustrated in Figs. 4 and 5.

Apparent second-order surface reaction rate coefficients $k_{\mathrm{SLR}, \mathrm{PAH}, \mathrm{O} 3}$ were derived assuming $k_{\mathrm{SLR}, \mathrm{O} 3, \mathrm{NO} 2}=0$, because no PAH degradation was observed upon exposure to $\mathrm{NO}_{2}$ without $\mathrm{O}_{3}$ (Pöschl, 2002; Schauer, 2004; Schauer et al., 2004). Interestingly, however, the measured and derived rate coefficients $k_{\mathrm{S}, \mathrm{PAH} \text {,max }}$ and $k_{\mathrm{SLR}, \mathrm{PAH}, \mathrm{O} 3}$ exhibit a systematic increase with increasing $\mathrm{NO}_{2}$ concentration. For example, $k_{\mathrm{SLR}, \mathrm{PAH}, \mathrm{O} 3}$ increases by a factor of $\sim 2$ from $2.66 \times 10^{-17} \mathrm{~cm}^{2} \mathrm{~s}^{-1}$ in the absence of $\mathrm{NO}_{2}$ to 
Table 3. Basic physicochemical parameters of $\mathrm{NO}_{2}$ in the $\mathrm{BaP}-\mathrm{O}_{3}-\mathrm{NO}_{2}-\mathrm{H}_{2} \mathrm{O}$ system on soot (Schauer, 2004).

\begin{tabular}{|c|c|c|c|c|c|c|c|}
\hline $\begin{array}{l}\mathrm{RH} \\
(\%)\end{array}$ & $\begin{array}{l}\mathrm{NO}_{2} \\
(\mathrm{ppb})\end{array}$ & $\begin{array}{c}K_{\mathrm{ads}, \mathrm{NO} 2} \\
\left(10^{-15} \mathrm{~cm}^{3}\right)\end{array}$ & $\begin{array}{c}{[\mathrm{SS}]_{\mathrm{ss}}} \\
\left(10^{14} \mathrm{~cm}^{-2}\right)\end{array}$ & $\begin{array}{c}k_{\mathrm{d}, \mathrm{NO} 2} \\
\left(\mathrm{~s}^{-1}\right)\end{array}$ & $\begin{array}{c}\tau_{\mathrm{d}, \mathrm{NO} 2} \\
(\mathrm{~s})\end{array}$ & $\begin{array}{c}\Delta H_{\mathrm{ads}, \mathrm{NO} 2} \\
\left(\mathrm{~kJ} \mathrm{~mol}^{-1}\right)\end{array}$ & Data set \\
\hline 0 & 100 & 82 & 4.50 & 16.0 & 0.062 & -70 & {$\left[\mathrm{O}_{3}\right]_{\mathrm{s}}$ vs. $\left[\mathrm{O}_{3}\right]_{\mathrm{gs}}$} \\
\hline 0 & 500 & 34 & 3.50 & 49.6 & 0.020 & -67 & {$\left[\mathrm{O}_{3}\right]_{\mathrm{s}}$ vs. $\left[\mathrm{O}_{3}\right]_{\mathrm{gs}}$} \\
\hline 0 & 1000 & 53 & 3.00 & 37.1 & 0.027 & -68 & {$\left[\mathrm{O}_{3}\right]_{\mathrm{s}}$ vs. $\left[\mathrm{O}_{3}\right]_{\mathrm{gs}}$} \\
\hline 25 & 1000 & 10 & 2.24 & 263 & 0.004 & -63 & {$\left[\mathrm{O}_{3}\right]_{\mathrm{s}}$ vs. $\left[\mathrm{O}_{3}\right]_{\mathrm{gs}}$} \\
\hline 0 & 100 & 69 & - & 19.0 & 0.053 & -69 & $k_{\mathrm{s}, \mathrm{BaP}}$ vs. $\left[\mathrm{O}_{3}\right]_{\mathrm{gs}}$ \\
\hline 0 & 250 & 54 & - & 27.3 & 0.037 & -68 & $k_{\mathrm{s}, \mathrm{BaP}}$ vs. $\left[\mathrm{O}_{3}\right]_{\mathrm{gs}}$ \\
\hline 25 & 250 & 86 & - & 17.2 & 0.058 & -70 & $k_{\mathrm{s}, \mathrm{BaP}}$ vs. $\left[\mathrm{O}_{3}\right]_{\mathrm{gs}}$ \\
\hline 0 & 500 & 71 & - & 23.8 & 0.042 & -69 & $k_{\mathrm{s}, \mathrm{BaP}}$ vs. $\left[\mathrm{O}_{3}\right]_{\mathrm{gs}}$ \\
\hline 0 & 750 & 17 & - & 99.2 & 0.010 & -65 & $k_{\mathrm{s}, \mathrm{BaP}}$ vs. $\left[\mathrm{O}_{3}\right]_{\mathrm{gs}}$ \\
\hline
\end{tabular}

Table 4. Basic physicochemical parameters of $\mathrm{O}_{3}$ in the $\mathrm{BaP}-\mathrm{O}_{3}-\mathrm{NO}_{2}-\mathrm{H}_{2} \mathrm{O}$ system on soot (Schauer, 2004).

\begin{tabular}{ccccccccc}
\hline $\begin{array}{c}\mathrm{RH} \\
(\%)\end{array}$ & $\begin{array}{c}\mathrm{NO}_{2} \\
(\mathrm{ppb})\end{array}$ & $\begin{array}{c}K_{\mathrm{ads}, \mathrm{O} 3} \\
\left(10^{-15} \mathrm{~cm}^{3}\right)\end{array}$ & $\begin{array}{c}k_{\mathrm{s}, \mathrm{PAH}, \max } \\
\left(\mathrm{s}^{-1}\right)\end{array}$ & $\begin{array}{c}{[\mathrm{SS}]_{\mathrm{ss}}} \\
\left(10^{14} \mathrm{~cm}^{-2}\right)\end{array}$ & $\begin{array}{c}k_{\mathrm{SLR}, \mathrm{PAH}, \mathrm{O} 3} \\
\left(10^{-17} \mathrm{~cm}^{2} \mathrm{~s}^{-1}\right)\end{array}$ & $\begin{array}{c}k_{\mathrm{d}, \mathrm{O} 3} \\
\left(\mathrm{~s}^{-1}\right)\end{array}$ & $\begin{array}{c}\tau_{\mathrm{d}, \mathrm{O} 3} \\
(\mathrm{~s})\end{array}$ & $\begin{array}{c}\Delta H_{\mathrm{ads}, \mathrm{O} 3} \\
\left(\mathrm{~kJ} \mathrm{~mol}^{-1}\right)\end{array}$ \\
\hline 0 & 0 & 255 & 0.015 & 5.80 & 2.66 & 0.06 & 16.3 & -86 \\
0 & 100 & 331 & 0.013 & 4.50 & 2.89 & 0.06 & 16.5 & -86 \\
0 & 250 & 369 & 0.015 & $4.00^{*}$ & 3.75 & 0.06 & 16.4 & -86 \\
25 & 250 & 332 & 0.021 & $4.00^{*}$ & 5.25 & 0.07 & 14.7 & -86 \\
0 & 500 & 347 & 0.020 & 3.50 & 5.71 & 0.07 & 13.5 & -86 \\
0 & 750 & 296 & 0.020 & $3.25^{*}$ & 6.15 & 0.09 & 10.7 & -85 \\
0 & 1000 & 513 & - & 3.00 & - & 0.06 & 17.1 & -86 \\
25 & 1000 & 474 & - & 2.24 & - & 0.09 & 11.8 & -85 \\
\hline
\end{tabular}

* Values in italic are interpolated.

$5.70 \times 10^{-17} \mathrm{~cm}^{2} \mathrm{~s}^{-1}$ at $500 \mathrm{ppb} \mathrm{NO}$. The accelerating effect of $\mathrm{NO}_{2}$ can be attributed to the formation of highly reactive $\mathrm{NO}_{3}$ radicals in the gas phase or on the surface. Other reactive nitrogen species like $\mathrm{N}_{2} \mathrm{O}_{5}$ or $\mathrm{HNO}_{3}$ are unlikely to play a major role because the uptake coefficients reported for them are $<10^{-5}$ (Gross and Bertram, 2008).

\section{Numerical modeling of transient conditions}

Here we simulate the temporal evolution of surface composition and uptake coefficients of ozone over timescales from microseconds to days under standard conditions (298 K, $1013 \mathrm{hPa}$ ). The model calculations were performed by solving the rate equations (Eq. 14-18) numerically with Matlab software (ode $23 \mathrm{~s}$ solver). No steady-state assumptions were applied in the numerical simulations.

The initial PAH surface concentration is set to $1 \times 10^{14} \mathrm{~cm}^{-2}$, and the initial surface concentration of gas species $\left(\mathrm{X}_{i}=\mathrm{O}_{3}, \mathrm{H}_{2} \mathrm{O}, \mathrm{NO}_{2}\right.$, and $\left.\mathrm{NO}_{3}\right)$ is set to zero. In the exemplary simulations, we consider soot and solid organic surfaces. The required basic physicochemical parameters are listed in Table 5. The $\alpha_{\mathrm{s}, 0}$ values were taken from earlier studies (Tabor et al., 1994; Rogaski et al., 1997). The $\tau_{\mathrm{d}}$ and $k_{\mathrm{SLR}, \mathrm{PAH}, \mathrm{O} 3}$ values were taken from Sect. 3 . The gas phase ozone concentration is set to $100 \mathrm{ppb}$, which is typical for polluted air masses. The chemical half-life of the PAH $\left(t_{1 / 2}\right)$ is defined as the time when the PAH concentration reaches half of the initial concentration.

\section{1 $\mathrm{PAH}-\mathrm{O}_{3}-\mathrm{H}_{2} \mathrm{O}$ system}

Here we simulate $\mathrm{PAH}$ degradation upon interaction with $\mathrm{O}_{3}$ and $\mathrm{H}_{2} \mathrm{O}$. Fig. 6 shows the surface concentrations of all involved chemical species and the uptake coefficient of $\mathrm{O}_{3}$ $\left(\gamma_{\mathrm{O} 3}\right)$. Figure 6a displays the model results for a soot surface at $25 \% \mathrm{RH}$. The initial plateau of $\gamma_{\mathrm{O} 3}$ is equal to $\alpha_{\mathrm{s}, 0, \mathrm{O} 3}$ $\left(=10^{-3}\right)$ up to $1 \mathrm{~s}$, which can be explained by adsorption of $\mathrm{O}_{3}$ onto a nearly adsorbate-free surface. The second plateau of $\gamma_{\mathrm{O} 3}$ at $\sim 10^{-5}$ is due to chemical reaction of $\mathrm{O}_{3}$ with PAH. Under dry conditions the model results are similar (not shown in figure), but due to the absence of competitively adsorbing $\mathrm{H}_{2} \mathrm{O}$ the surface coverage of $\mathrm{O}_{3}$ increases and the PAH chemical half-life decreases $188 \mathrm{~s}(25 \% \mathrm{RH})$ to $168 \mathrm{~s}$ (dry). 
Table 5. Basic physicochemical parameters of $\mathrm{O}_{3}, \mathrm{H}_{2} \mathrm{O}$, and $\mathrm{NO}_{2}$ used in the numerical simulations of transient conditions.

\begin{tabular}{llccccc}
\hline $\mathrm{X}_{i}$ & Substrate & $\begin{array}{c}K_{\mathrm{ads}, \mathrm{X}_{i}} \\
\left(10^{-15} \mathrm{~cm}^{3}\right)\end{array}$ & $\begin{array}{c}k_{\mathrm{SLR}, \mathrm{PAH}, \mathrm{O} 3} \\
\left(10^{-17} \mathrm{~cm}^{2} \mathrm{~s}^{-1}\right)\end{array}$ & $\begin{array}{c}\tau_{\mathrm{d}, \mathrm{X} i} \\
(\mathrm{~s})\end{array}$ & $\alpha_{\mathrm{s}, 0, \mathrm{X} i}$ & $\begin{array}{c}\omega_{\mathrm{X} i} \\
\left(\mathrm{~cm} \mathrm{~s}^{-1}\right)\end{array}$ \\
\hline $\mathrm{O}_{3}$ & soot & 160 & 2.7 & 10 & $10^{-3}$ & $3.60 \times 10^{4}$ \\
& solid organic & $1.6-16$ & 2.7 & $0.1-1$ & $10^{-3}$ & $3.60 \times 10^{4}$ \\
& liquid & $0.16-1.6$ & 0.5 & $0.01-0.1$ & $10^{-3}$ & $3.60 \times 10^{4}$ \\
$\mathrm{H}_{2} \mathrm{O}$ & & $10^{-3}$ & - & $10^{-4}$ & $4.0 \times 10^{-4}$ & $5.90 \times 10^{4}$ \\
$\mathrm{NO}_{2}$ & & 50 & - & 0.05 & 0.064 & $3.69 \times 10^{4}$ \\
\hline
\end{tabular}
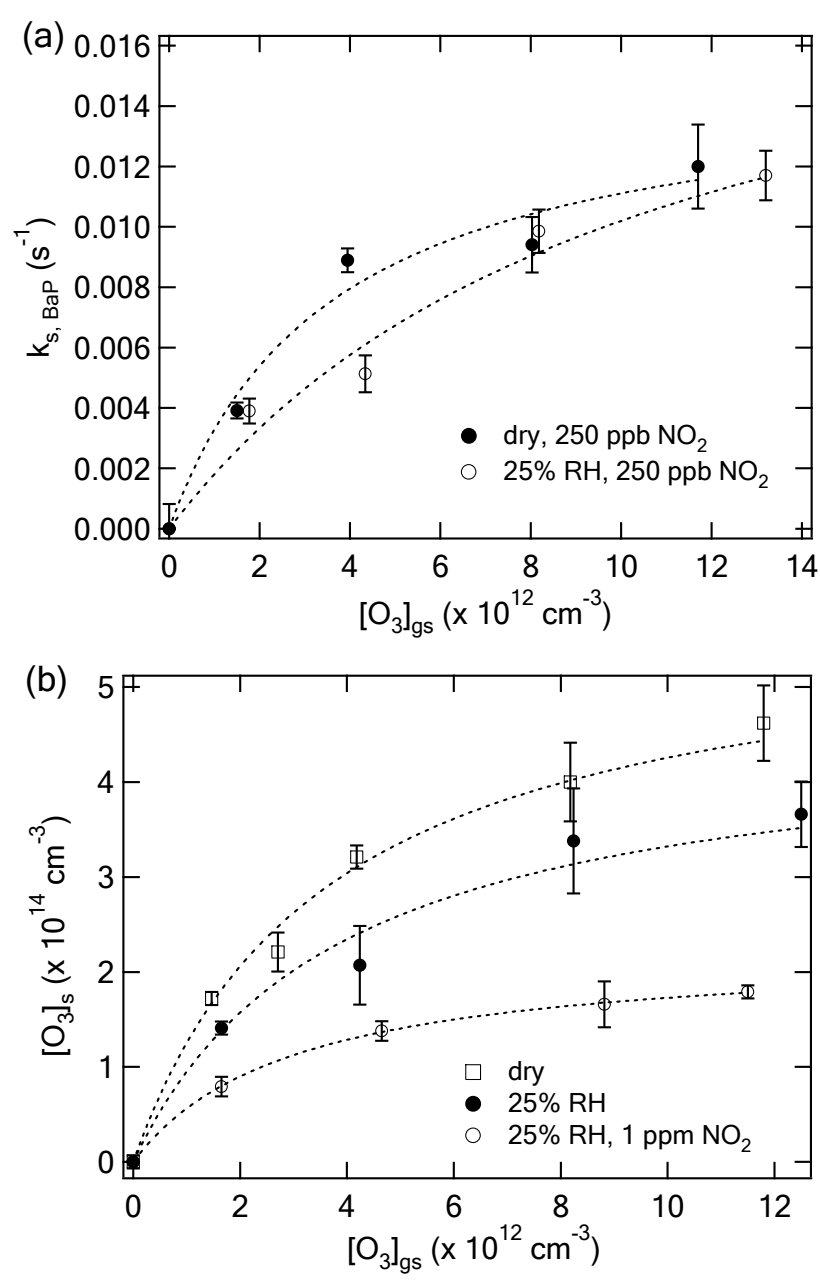

Fig. 5. Experimental data and fit lines for the $\mathrm{BaP}-\mathrm{O}_{3}-\mathrm{NO}_{2}-\mathrm{H}_{2} \mathrm{O}$ system (Schauer, 2004). (a) Pseudo-first-order BaP decay coefficients $\left(k_{\mathrm{s}, \mathrm{BaP}}\right)$ as a function of gas phase ozone concentration $\left(\left[\mathrm{O}_{3}\right]_{\mathrm{gs}}\right)$ under dry and wet $(25 \% \mathrm{RH})$ conditions with $250 \mathrm{ppb}$ $\mathrm{NO}_{2}$. (b) The surface concentration of ozone $\left(\left[\mathrm{O}_{3}\right]_{\mathrm{S}}\right)$ as a function of $\left[\mathrm{O}_{3}\right]_{\mathrm{gs}}$. The data were measured under dry, wet $(25 \% \mathrm{RH})$, and wet $(25 \% \mathrm{RH})$ and $\mathrm{NO}_{2}(1 \mathrm{ppm})$ conditions. Fit curves assume a Langmuir-Hinshelwood-type mechanism.
Fig. $6 \mathrm{~b}$ displays the model results for a solid organic surface at $25 \% \mathrm{RH}$. Under these conditions the dominant species on the surface is $\mathrm{H}_{2} \mathrm{O}$, and the $\mathrm{O}_{3}$ surface concentration is much lower than on soot. Consequently, the PAH degradation proceeds slower and the second plateau of $\gamma_{\mathrm{O} 3}$ is longer $\left(\sim 10^{4} \mathrm{~s}\right)$ and lower $\left(\gamma_{\mathrm{O} 3}=\times 10^{-7}\right)$.

The differences of PAH degradation on soot and on the solid organic surface are mainly caused by the different desorption lifetimes of ozone as derived and discussed in Sect. 3 $(\sim 10 \mathrm{~s}$ vs. $\sim 0.1 \mathrm{~s})$. We speculate that the longer apparent desorption lifetime on soot may reflect stronger electron donor-acceptor interactions between the graphene layers (aromatic rings) and the adsorbed ozone molecules or oxygen atoms, respectively.

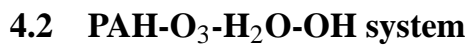

Here we simulate PAH degradation by $\mathrm{O}_{3}, \mathrm{H}_{2} \mathrm{O}$, and $\mathrm{OH}$ radicals for which we assume an elementary surface reaction probability of $\gamma_{\mathrm{GSR}, \mathrm{OH}, \mathrm{PAH}}=0.32$ (Bertram et al., 2001). The two dotted lines in Fig. $6 \mathrm{a}$ and $6 \mathrm{~b}$ correspond to different $\mathrm{OH}$ concentration levels: an estimated global average value of $[\mathrm{OH}]_{\mathrm{g}}=10^{6} \mathrm{~cm}^{-3}$ ) (Prinn et al., 1992) and an approximate upper limit value of $[\mathrm{OH}]_{\mathrm{g}}=10^{7} \mathrm{~cm}^{-3}$. The near-surface gas phase concentration $[\mathrm{OH}]_{\mathrm{gs}}$ was calculated from Eqs. (2) and (3) assuming a particle diameter of $200 \mathrm{~nm}\left(C_{\mathrm{g}, \mathrm{OH}}=0.87\right)$.

Figure 6a indicates that $\mathrm{OH}$ does not significantly affect PAH degradation on soot, where ozone is strongly adsorbed and plays a dominant role. On the solid organic surface, however, where ozone is less efficiently adsorbed, $\mathrm{OH}$ strongly accelerates PAH degradation as shown in Fig. 6b. Consequently, the PAH decay proceeds faster and the length of the second plateau of $\gamma_{\mathrm{O} 3}$ decreases with increasing $\mathrm{OH}$ concentration.

\subsubsection{PAH chemical half-life on the surface and atmospheric implications}

Here we simulate the chemical half-life of PAH $\left(t_{1 / 2}\right)$ on soot, organic and liquid surfaces, when exposed to ambient concentrations of $\mathrm{O}_{3}$ and $\mathrm{OH}$ at $25 \% \mathrm{RH}$. 

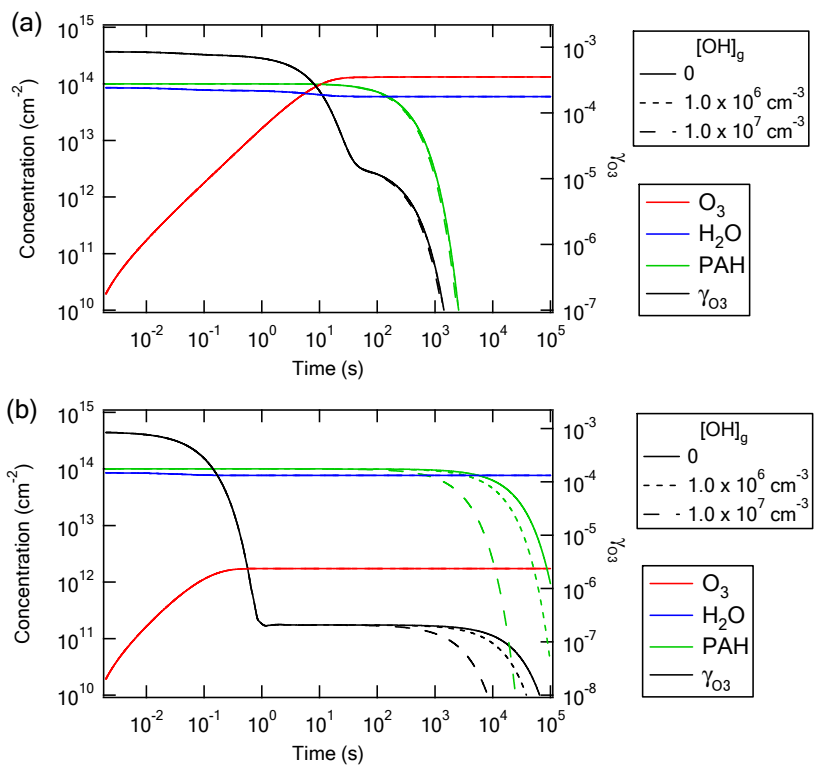

Fig. 6. Temporal evolution of the surface concentration of the volatile species $\left(\mathrm{O}_{3}\right.$ and $\left.\mathrm{H}_{2} \mathrm{O}\right)$, of PAH in the quasi-static surface layer, and of the ozone uptake coefficient $\left(\gamma_{\mathrm{O} 3}\right)$ at $100 \mathrm{ppb}$ $\mathrm{O}_{3}$ and $25 \% \mathrm{RH}$ assuming $\mathrm{OH}$ concentration of 0 (solid line), $1.0 \times 10^{6} \mathrm{~cm}^{-3}$ (dotted line) and $1.0 \times 10^{6} \mathrm{~cm}^{-3}$ (dashed line). PAHs are either (a) on soot or (b) on a solid organic surface.

Figure 7 displays the results of calculations. The black line is the $t_{1 / 2}$ of PAH on a soot surface, which showed $t_{1 / 2}$ of $\sim 10$ min at typical atmospheric $\mathrm{O}_{3}$ concentration of $30 \mathrm{ppb}$. We calculated $t_{1 / 2}$ under dry conditions as well, which resulted in a $t_{1 / 2}$ value of $\sim 5 \mathrm{~min}$ at $30 \mathrm{ppb} \mathrm{\textrm {O } _ { 3 }}$. Therefore, the competitive adsorption of $\mathrm{O}_{3}$ and $\mathrm{H}_{2} \mathrm{O}$ leads to a significant increase in $t_{1 / 2}$. However, the $t_{1 / 2}$ values showed only a slight change with increasing $[\mathrm{OH}]_{\mathrm{g}}$. This is because PAH degradation on soot is dominated by the surface layer reaction of $\mathrm{PAH}$ with $\mathrm{O}_{3}$.

The $t_{1 / 2}$ values on a solid organic surface (red and blue line) are estimated to $2-15 \mathrm{~h}$ at $30 \mathrm{ppb} \mathrm{O}_{3}$ when $[\mathrm{OH}]_{\mathrm{g}}$ is 0 . The $t_{1 / 2}$ value on a liquid surface like octanol and water (green line) is estimated to a few days. As shown in Fig. 7, $\tau_{\mathrm{d}, \mathrm{O} 3}$ is a critical factor in estimating the chemical half-life of PAH on the surface. OH plays a critical role in these cases. It accelerates the PAH degradation by one to two orders of magnitude depending on $\mathrm{OH}$ concentration.

In summary, the PAH chemical half-life on the surface $\left(t_{1 / 2}\right)$ ranges from $\sim 10 \mathrm{~min}$ on soot, to $1-5 \mathrm{~h}$ on solid organics and $6 \mathrm{~h}$ on liquid particles under typical ambient conditions $\left(30 \mathrm{ppb} \mathrm{O}_{3}, 25 \% \mathrm{RH}, 10^{6} \mathrm{~cm}^{-3} \mathrm{OH}\right)$. Therefore, the relative importance of $\mathrm{PAH}$ degradation by $\mathrm{O}_{3}$ and $\mathrm{OH}$ depends on the substrate of PAH.

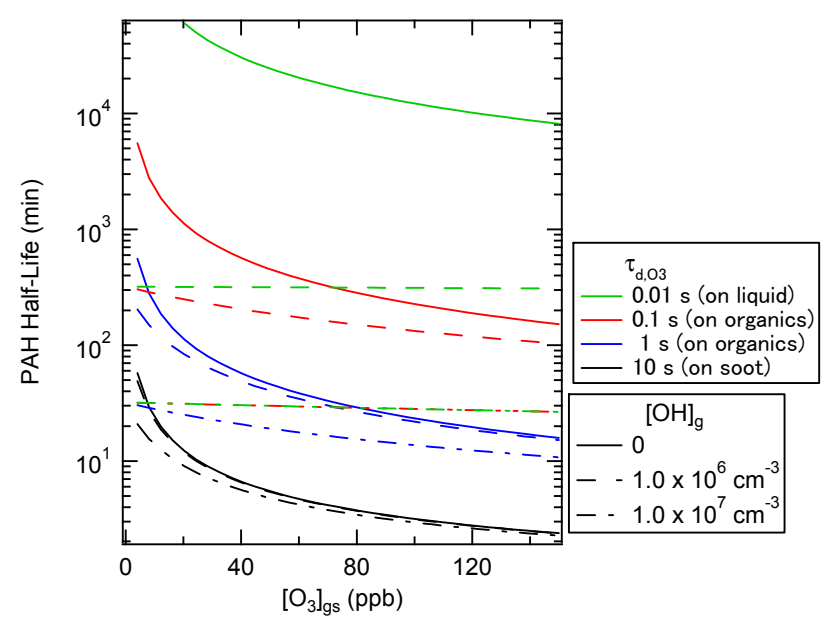

Fig. 7. Chemical half-life of PAHs on different substrates (soot, solid organic, liquid) as a function of gas phase ozone concentration at $25 \% \mathrm{RH}$ assuming $\mathrm{OH}$ concentrations of 0 (solid lines), $1.0 \times 10^{6} \mathrm{~cm}^{-3}$ (dashed lines), and $1.0 \times 10^{7} \mathrm{~cm}^{-3}$ (dotted lines). The desorption lifetime of $\mathrm{O}_{3}\left(\tau_{\mathrm{d}, \mathrm{O} 3}\right)$ was set to $10 \mathrm{~s}$ (soot), 1 or $0.1 \mathrm{~s}$ (solid organic), and $0.01 \mathrm{~s}$ (liquid), respectively.

\section{3 $\mathrm{PAH}-\mathrm{O}_{3}-\mathrm{H}_{2} \mathrm{O}-\mathrm{NO}_{2}-\mathrm{NO}_{3}$ system}

Here we simulate PAH degradation on soot upon interactions with $\mathrm{O}_{3}, \mathrm{H}_{2} \mathrm{O}, \mathrm{NO}_{2}$, and $\mathrm{NO}_{3}$. As shown in Table 4, $\mathrm{NO}_{2}$ could accelerate $\mathrm{PAH}$ degradation. For example, the apparent $k_{\mathrm{SLR}, \mathrm{PAH}, \mathrm{O} 3}$ is increased from $2.7 \times 10^{-17} \mathrm{~cm}^{2} \mathrm{~s}^{-1}$ to $5.7 \times 10^{-17} \mathrm{~cm}^{2} \mathrm{~s}^{-1}$ under $500 \mathrm{ppb} \mathrm{NO}$, leading to a reduction of $t_{1 / 2}$ from $188 \mathrm{~s}$ to $170 \mathrm{~s}$ at $100 \mathrm{ppb} \mathrm{O}_{3}$ and $25 \%$ $\mathrm{RH}$. Here we consider two possible explanations for the acceleration of $\mathrm{PAH}$ degradation by $\mathrm{NO}_{2}$ : (1) surface reaction of $\mathrm{O}_{3}$ with $\mathrm{NO}_{2}$ (Langmuir-Hinshelwood-type mechanism) and (2) gas-surface reaction between PAH and gas phase $\mathrm{NO}_{3}$ radical (Eley-Rideal-type mechanism).

\subsubsection{Surface reaction of $\mathrm{O}_{3}$ with $\mathrm{NO}_{2}$}

Here we simulate degradation of PAH on soot upon interactions with $\mathrm{O}_{3}, \mathrm{NO}_{2}$ and $\mathrm{H}_{2} \mathrm{O}$ considering a surface reaction of $\mathrm{O}_{3}$ with $\mathrm{NO}_{2}$ (SLR2) and the subsequent reaction of $\mathrm{NO}_{3}$ with PAH (SLR3). We tested $k_{\mathrm{SLR}, \mathrm{O} 3, \mathrm{NO} 2}$ and $k_{\mathrm{SLR}, \mathrm{PAH}, \mathrm{NO} 3}$ values in the range of $10^{-18}-10^{-11} \mathrm{~cm}^{2} \mathrm{~s}^{-1}$. The desorption lifetime of $\mathrm{NO}_{3}\left(\tau_{\mathrm{d}, \mathrm{NO} 3}\right)$ was assumed to be 10 and $0.01 \mathrm{~s}$. The concentration of $\mathrm{NO}_{2}$ at $25 \% \mathrm{RH}$ is set to $500 \mathrm{ppb}$. The resulting PAH chemical half-lifes $\left(t_{1 / 2}\right)$ are summarized in Table 6.

The $t_{1 / 2}$ value should be $\sim 170 \mathrm{~s}$ considering the acceleration of $\mathrm{PAH}$ degradation as discussed above. Moreover, the fact that the $\mathrm{PAH}-\mathrm{O}_{3}-\mathrm{H}_{2} \mathrm{O}-\mathrm{NO}_{2}$ system is well described by Langmuir-Hinshelwood-type mechanism (Fig. 5) indicates $L_{\mathrm{SLR}, \mathrm{O} 3} \ll J_{\mathrm{des}, \mathrm{O} 3}$, leading to $k_{\mathrm{s}, \mathrm{O} 3}\left(=k_{\mathrm{SLR}, \mathrm{PAH}, \mathrm{O} 3}[\mathrm{PAH}]_{\mathrm{ss}}+k_{\mathrm{SLR}, \mathrm{O} 3, \mathrm{NO} 2}\left[\mathrm{NO}_{2}\right]_{\mathrm{s}}\right) \ll k_{\mathrm{d}, \mathrm{O} 3}$. 
Table 6. Chemical half-life of PAHs in the PAH- $\mathrm{O}_{3}-\mathrm{NO}_{2}-\mathrm{H}_{2} \mathrm{O}$ system assuming different values for the $\mathrm{O}_{3}-\mathrm{NO}_{2}$ and $\mathrm{PAH}-\mathrm{NO}_{3}$ surface layer reaction rate coefficients $\left(k_{\mathrm{SLR}, \mathrm{O} 3, \mathrm{NO} 2}, k_{\mathrm{SLR}, \mathrm{PAH}, \mathrm{NO} 3}\right)$.

\begin{tabular}{lrrrrr}
\hline$\tau_{\mathrm{d}, \mathrm{NO} 3}=10 \mathrm{~s}$ & $t_{1 / 2}(\mathrm{~s})$ & \multicolumn{4}{c}{$k_{\mathrm{SLR}, \mathrm{PAH}, \mathrm{NO} 3}\left(\mathrm{~cm}^{2} \mathrm{~s}^{-1}\right)$} \\
\cline { 3 - 6 } & & $10^{-17}$ & $10^{-16}$ & $10^{-14}$ & $10^{-11}$ \\
\hline$k_{\mathrm{SLR}, \mathrm{O}, \mathrm{NO} 2}$ & $10^{-18}$ & 263 & 262 & 245 & 242 \\
$\left(\mathrm{~cm}^{2} \mathrm{~s}^{-1}\right)$ & $10^{-17}$ & 265 & 253 & 154 & 145 \\
& $10^{-16}$ & 287 & 197 & 41 & 36 \\
\hline
\end{tabular}

\begin{tabular}{lrrrrr}
\hline$\tau_{\mathrm{d}, \mathrm{NO} 3}=0.01 \mathrm{~s}$ & $t_{1 / 2}(\mathrm{~s})$ & \multicolumn{4}{c}{$k_{\mathrm{SLR}, \mathrm{PAH}, \mathrm{NO} 3}\left(\mathrm{~cm}^{2} \mathrm{~s}^{-1}\right)$} \\
\cline { 3 - 6 } & & $10^{-17}$ & $10^{-16}$ & $10^{-14}$ & $10^{-11}$ \\
\hline$k_{\mathrm{SLR}, \mathrm{O} 3, \mathrm{NO} 2}$ & $10^{-18}$ & 263 & 263 & 263 & 244 \\
$\left(\mathrm{~cm}^{2} \mathrm{~s}^{-1}\right)$ & $10^{-17}$ & 266 & 266 & 264 & 153 \\
& $10^{-16}$ & 297 & 297 & 280 & 40 \\
\hline
\end{tabular}

Considering $k_{\mathrm{d}, \mathrm{O} 3}$ is $\sim 10^{-1}$ and $\left[\mathrm{NO}_{2}\right]_{\mathrm{s}}$ and $[\mathrm{PAH}]_{\mathrm{ss}}$ is $\sim 10^{14}$, then $k_{\mathrm{SLR}, \mathrm{O} 3, \mathrm{NO} 2}$ should be $<10^{-16}$.

Based on these criteria, $k_{\mathrm{SLR}, \mathrm{O} 3, \mathrm{NO} 2}$ should be of the order of $10^{-17}-10^{-16} \mathrm{~cm}^{2} \mathrm{~s}^{-1}$, whereas $k_{\mathrm{SLR}, \mathrm{PAH}, \mathrm{NO}}$ is of the order of $10^{-15}-10^{-12} \mathrm{~cm}^{2} \mathrm{~s}^{-1}$. This is reasonable because $k_{\mathrm{SLR}, \mathrm{O} 3, \mathrm{NO} 2}$ is on the same order of $k_{\mathrm{SLR}, \mathrm{PAH}, \mathrm{O} 3}$ and the $\mathrm{NO}_{3}$ radical is expected to have high reactivity. The possible combination of rate coefficients are (1) $\tau_{\mathrm{d}, \mathrm{NO} 3}=10 \mathrm{~s}$, $k_{\mathrm{SLR}, \mathrm{O} 3, \mathrm{NO} 2}=10^{-17}-10^{-16} \mathrm{~cm}^{2} \mathrm{~s}^{-1}, \quad k_{\mathrm{SLR}, \mathrm{PAH}, \mathrm{NO} 3}=10^{-15}$ $10^{-14} \mathrm{~cm}^{2} \mathrm{~s}^{-1}$ and (2) $\tau_{\mathrm{d}, \mathrm{NO} 3}=0.01 \mathrm{~s}, k_{\mathrm{SLR}, \mathrm{O} 3, \mathrm{NO} 2}=10^{-17}$ $10^{-16} \mathrm{~cm}^{2} \mathrm{~s}^{-1}, k_{\mathrm{SLR}, \mathrm{PAH}, \mathrm{NO} 3}=10^{-13}-10^{-12} \mathrm{~cm}^{2} \mathrm{~s}^{-1}$.

Figure 8a shows the exemplary simulation of this system using $\tau_{\mathrm{d}, \mathrm{NO} 3}=10 \mathrm{~s}, k_{\mathrm{SLR}, \mathrm{O} 3, \mathrm{NO} 2}=10^{-17} \mathrm{~cm}^{2} \mathrm{~s}^{-1}$, and $k_{\mathrm{SLR}, \mathrm{PAH}, \mathrm{NO} 3}=10^{-14} \mathrm{~cm}^{2} \mathrm{~s}^{-1}$. Temporal evolution is similar to Fig. 6a, but the PAH degradation was accelerated by formation of $\mathrm{NO}_{3}$ radical, whose concentration reaches $\sim 10^{12} \mathrm{~cm}^{-2}$. The uptake coefficient of $\mathrm{O}_{3}\left(\gamma_{\mathrm{O} 3}\right)$ stayed $10^{-5}$ because of continuous surface reaction of $\mathrm{O}_{3}$ with $\mathrm{NO}_{2} . \gamma_{\mathrm{NO} 2}$ was also calculated and it was 0.064 initially up to $10^{-2} \mathrm{~s}$, which is equal to $\alpha_{\mathrm{s}, 0, \mathrm{NO} 2}$. As it is shown by $\left[\mathrm{NO}_{2}\right]_{\mathrm{s}}$ which reached steady-state condition quickly, $\gamma_{\mathrm{NO} 2}$ decreased away after $0.1 \mathrm{~s}$.

\subsubsection{Gas-surface reaction with $\mathrm{NO}_{3}$}

Gas-surface reaction between gas phase $\mathrm{NO}_{3}$ radicals and $\mathrm{PAH}$ is another possible explanation for the acceleration of PAH degradation. This system corresponds to a possible nighttime chemistry of PAH degradation, as $\mathrm{NO}_{3}$ is the dominant oxidant at nighttime.

Here we simulate $\mathrm{PAH}$ degradation by $\mathrm{O}_{3}, \mathrm{H}_{2} \mathrm{O}, \mathrm{NO}_{2}$, and gas phase $\mathrm{NO}_{3}$ radicals for which we assume an elementary surface reaction probability of $\gamma_{\mathrm{GSR}, \mathrm{OH}, \mathrm{PAH}}=0.13$ (Rudich et al., 1996). Note that the surface reaction of $\mathrm{O}_{3}$ with $\mathrm{NO}_{2}$ is
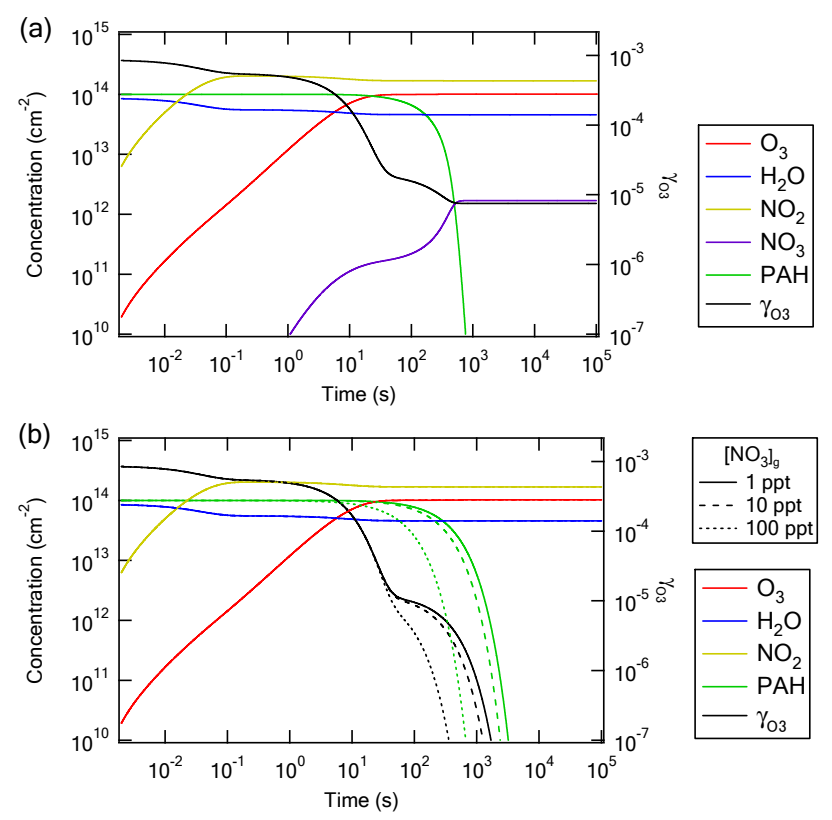

Fig. 8. Temporal evolution of the surface concentrations of PAHs and volatile species $\left(\mathrm{O}_{3}\right.$ and $\left.\mathrm{H}_{2} \mathrm{O}\right)$ on soot, and of the ozone uptake

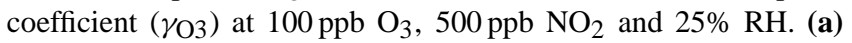
$\mathrm{PAH}-\mathrm{O}_{3}-\mathrm{H}_{2} \mathrm{O}-\mathrm{NO}_{2}$ system considering surface reaction of $\mathrm{O}_{3}$ with $\mathrm{NO}_{2}$. (b) $\mathrm{PAH}-\mathrm{O}_{3}-\mathrm{H}_{2} \mathrm{O}-\mathrm{NO}_{2}-\mathrm{NO}_{3}$ system assuming $\mathrm{NO}_{3}$ concentrations of $1 \mathrm{ppt}$ (solid line), $10 \mathrm{ppt}$ (dashed line) and $100 \mathrm{ppt}$ (dotted line), respectively.

not considered in this simulation. The near-surface gas phase concentration $\left[\mathrm{NO}_{3}\right]_{\mathrm{gs}}$ was calculated from Eqs. (2) and (3) assuming a particle diameter of $200 \mathrm{~nm}\left(C_{\mathrm{g}, \mathrm{NO} 3}=0.94\right)$. The $\mathrm{NO}_{2}$ concentration at $25 \% \mathrm{RH}$ is set to $500 \mathrm{ppb}$. Four $\mathrm{NO}_{3}$ concentrations that cover the range of ambient concentrations $(1,10,20$, and $100 \mathrm{ppt})$ are assumed (Finlayson-Pitts and Pitts, 2000).

Figure $8 \mathrm{~b}$ indicates that the presence of $\mathrm{NO}_{3}$ does not impact the degradation of PAHs significantly when $\left[\mathrm{NO}_{3}\right]_{\mathrm{g}}=1 \mathrm{ppt}$, , but rather ozone plays a dominant role in $\mathrm{PAH}$ degradation. The $\mathrm{NO}_{3}$ radicals compensate the competitive adsorption of $\mathrm{NO}_{2}$ when $\left[\mathrm{NO}_{3}\right]_{\mathrm{g}}=10 \mathrm{ppt}$ with $t_{1 / 2}$ of $186 \mathrm{~s}$. The $t_{1 / 2}$ is $144 \mathrm{~s}$ when $\left[\mathrm{NO}_{3}\right]_{\mathrm{g}}=20 \mathrm{ppt}$. And for $\left[\mathrm{NO}_{3}\right]_{\mathrm{g}}=100 \mathrm{ppt}$, the $t_{1 / 2}$ is calculated to $38 \mathrm{~s}$, indicating PAH degradation is dominated by the $\mathrm{NO}_{3}$ radical at this condition.

\subsubsection{PAH chemical half-life on the surface and atmospheric implications}

Here we simulate the chemical half-life of PAH $\left(t_{1 / 2}\right)$ on soot, organic and liquid surfaces, when exposed to $\mathrm{O}_{3}, \mathrm{H}_{2} \mathrm{O}$, $\mathrm{NO}_{2}$, and $\mathrm{NO}_{3}$ at typical ambient concentration level at night time ( $\left.<150 \mathrm{ppb} \mathrm{O}_{3}, 60 \% \mathrm{RH}, 100 \mathrm{ppb} \mathrm{NO}_{2}, 1-10 \mathrm{ppt} \mathrm{NO}\right)_{3}$ ). Note that at higher RH water vapor may undergo multilayer adsorption and its effect may thus not be well described 


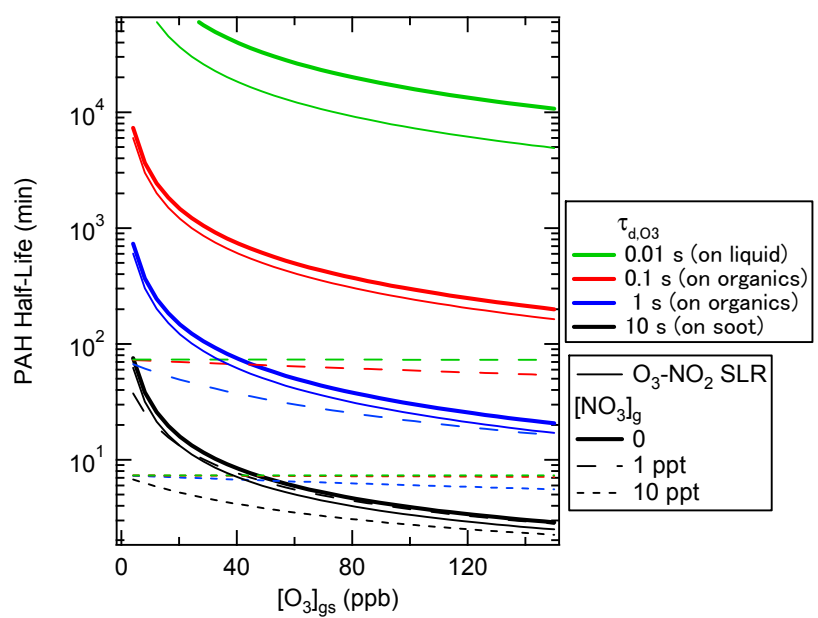

Fig. 9. Chemical half-life of PAHs on different substrates (soot, solid organic, liquid) as a function of gas phase ozone concentration at $100 \mathrm{ppb} \mathrm{NO} 2$ and $60 \% \mathrm{RH}$. The desorption lifetime of $\mathrm{O}_{3}\left(\tau_{\mathrm{d}, \mathrm{O}}\right)$ is set to $10 \mathrm{~s}$ (soot), 1 or $0.1 \mathrm{~s}$ (solid organic), and $0.01 \mathrm{~s}$ (liquid), respectively. The assumed $\mathrm{NO}_{3}$ gas phase concentrations are 0 (thick solid lines), 1 ppt (dashed lines), and $10 \mathrm{ppt}$ (dotted lines), respectively. Thin solid lines indicate that $\mathrm{O}_{3}-\mathrm{NO}_{2}$ surface layer reactions are taken into account assuming $\left[\mathrm{NO}_{3}\right]_{\mathrm{g}}=0$.

by a Langmuir adsorption isotherm (Thomas et al., 1999; Mikhailov et al., 2009). Figure 9 displays the results of calculations. Neither the surface reaction of $\mathrm{O}_{3}$ with $\mathrm{NO}_{2}$ nor gas-surface reaction of $\mathrm{NO}_{3}$ was considered for the thick solid line. $\mathrm{NO}_{3}$ accelerates the $\mathrm{PAH}$ degradation by one to three orders of magnitude depending on $\mathrm{NO}_{3}$ concentration (dotted and dashed line). The surface reaction of $\mathrm{O}_{3}$ and $\mathrm{NO}_{2}$ decreases the $t_{1 / 2}$ by ca. $40 \%$ on every surface (solid line).

In summary, under typical ambient conditions at night time (i.e. 30 ppb O$_{3}, 100$ ppb NO $2,60 \%$ RH, 1 ppt NO N $_{3}$ ), $t_{1 / 2}$ ranges from $\sim 10 \mathrm{~min}$ on soot, to $30-60 \mathrm{~min}$ on solid organics and liquid particles.

\section{Conclusions}

We have developed and applied a kinetic double-layer surface model (K2-SURF) and chemical reaction mechanism to describe the degradation of polycyclic aromatic hydrocarbons (PAHs) on aerosol particles interacting with ozone, nitrogen dioxide, water vapor, hydroxyl and nitrate radicals. Basic physicochemical parameters have been derived from experimental data and used to simulate PAH degradation and ozone uptake by aerosol particles under a wide range of conditions. The main conclusions are:

(1) The heterogeneous reaction between particle-bound PAHs and ozone can be well described by LangmuirHinshelwood-type mechanism and rate equations with effective Langmuir adsorption constants and surface
Table A1. Frequently used symbols.

\begin{tabular}{ll}
\hline Symbol & Meaning \\
\hline$\gamma_{\mathrm{X} i}$ & uptake coefficient of $\mathrm{X}_{i}$ \\
$\tau_{\mathrm{d}, \mathrm{X} i}$ & desorption lifetime of $\mathrm{X}_{i}$ \\
$\omega_{\mathrm{X} i}$ & mean thermal velocity of $\mathrm{X}_{i}$ in the gas phase \\
$C_{\mathrm{g}, \mathrm{X} i}$ & gas phase diffusion correction factor of $\mathrm{X}_{i}$ \\
$d_{\mathrm{p}}$ & particle diameter \\
$k_{\mathrm{d}, \mathrm{X} i}$ & first-order desorption rate coefficient of $\mathrm{X}_{i}$ \\
$k_{\mathrm{SLR} v, \mathrm{X} p, \mathrm{X} q}$, & second-order rate coefficients for surface \\
$k_{\mathrm{SLR} v, \mathrm{X} p, \mathrm{Y} q}$ & layer reactions of $\mathrm{X}_{p}$ with $\mathrm{X}_{q}, \mathrm{X}_{p}$ with $\mathrm{Y}_{q}$, \\
& respectively \\
$K_{\mathrm{ads}, \mathrm{X} i}$ & adsorption equilibrium constant of $\mathrm{X}_{i}$ \\
$K^{\prime}{ }_{\mathrm{ads}, \mathrm{X} i}$ & effective adsorption equilibrium constant of $\mathrm{X}_{i}$ \\
$\alpha_{\mathrm{s}, 0, \mathrm{X} i}$ & surface accommodation coefficient of $\mathrm{X}_{i}$ \\
$t_{1 / 2}$ & on an adsorbate-free surface \\
{$[\mathrm{SS}]_{\mathrm{ss}}$} & chemical half-life of PAHs on the surface \\
{$\left[\mathrm{X}_{i}\right]_{\mathrm{g}}$} & sorption site surface concentration \\
{$\left[\mathrm{X}_{i}\right]_{\mathrm{gs}}$} & gas phase concentration of $\mathrm{X}_{i}$ \\
{$\left[\mathrm{X}_{i}\right]_{\mathrm{s}}$} & near-surface gas phase concentration of $\mathrm{X}_{i}$ \\
{$\left[\mathrm{Y}_{j}\right]_{\mathrm{ss}}$} & surface concentration of $\mathrm{X}_{i}$ (sorption layer) \\
\hline & surface concentration of $\mathrm{Y}_{j}$ (quasi-static layer) \\
\hline
\end{tabular}

reaction rate coefficients depending on the substrate material. Note, however, that the exact reaction mechanisms, rate limiting steps and possible intermediates still remain to be resolved (e.g., surface diffusion and formation of $\mathrm{O}$ atoms or $\mathrm{O}_{3}^{-}$ions at the surface).

(2) Competitive and reversible adsorption and chemical transformation of the surface (aging) lead to a strong non-linear dependence of the ozone uptake coefficients on time and gas phase composition with different characteristic features under dilute atmospheric and concentrated laboratory conditions. Under typical ambient conditions the ozone uptake coefficients of PAH-coated aerosol particles are likely in the range of $10^{-6}-10^{-5}$.

(3) Nitrogen dioxide undergoes competitive co-adsorption with ozone. At ambient temperatures $\mathrm{NO}_{2}$ alone does not efficiently degrade PAHs, but it can accelerate PAH degradation by ozone. The accelerating effect of $\mathrm{NO}_{2}$ can be explained by the formation of highly reactive $\mathrm{NO}_{3}$ radicals in the gas phase and on the surface.

(4) The chemical half-life of PAH is expected to range from a few minutes on the surface of soot, to multiple hours on solid organics and days on liquid particles. On soot, PAH degradation appears to be dominated by a surface layer reaction with adsorbed $\mathrm{O}_{3}$ (LangmuirHinshelwood-type mechanism). On other substrates, it seems to be dominated by gas-surface reaction with $\mathrm{OH}$ and $\mathrm{NO}_{3}$ radicals (Eley-Rideal-type mechanism). 
(5) To our knowledge, K2-SURF is the first atmospheric process model describing multiple types of parallel and sequential surface reactions between multiple gaseous and particle-bound chemical species. We propose that K2-SURF may be used to design, analyze, and interpret experiments for better understanding of heterogeneous reaction systems. For example, systematic sensitivity studies can help to determine the range of experimental conditions (reactant concentrations, reaction time, etc.) that are likely to provide most information and direct insight into possible reaction mechanisms and the underlying physicochemical parameters (e.g., Langmuir-Hinselwood-type vs. Eley-Rideal-type mechanisms, physisorption vs. chemisorption, adsorption/desorption vs. chemical reaction rate coefficients, etc.). Moreover, we suggest that K2-SURF may serve as a basis for the development of a general master mechanism of aerosol and cloud surface chemistry.

Acknowledgements. This work was funded by the Max Planck Society (MPG) and the European integrated project on cloud climate and air quality interactions (No 036833-2, EUCAARI). MS is supported by the Max Planck Graduate Center - Johannes Gutenberg University Mainz (MPGC-JOGU), and the Ministry of Education, Culture, Sports, Science and Technology - Japan (MEXT). We thank N. Kwamena, J. P. D. Abbatt, T. Kahan and J. Donaldson for providing experimental data; J. Crowley, M. Ammann, N. Donahue, M. Rossi, T. Mentel, Y. Dubowski, Y. Iinuma, C. Pfrang, N. Kwamena and two anonymous referees for stimulating comments and discussions; and $\mathrm{H}$. Su for support in model development.

The service charges for this open access publication have been covered by the Max Planck Society.

Edited by: V.-M. Kerminen

\section{References}

Ackerman, A. S., Toon, O. B., Stevens, D. E., Heymsfield, A. J., Ramanathan, V., and Welton, E. J.: Reduction of tropical cloudiness by soot, Science, 288, 1042-1047, 2000.

Alebic-Juretic, A., Cvitas, T. and Klasinc, L.: Heterogeneous polycyclic aromatic hydrocarbon degradation with ozone on silicagel carrier, Environ. Sci. Technol., 24, 62-66, 1990.

Ammann, M. and Pöschl, U.: Kinetic model framework for aerosol and cloud surface chemistry and gas-particle interactions - Part 2: Exemplary practical applications and numerical simulations, Atmos. Chem. Phys., 7, 6025-6045, 2007,

http://www.atmos-chem-phys.net/7/6025/2007/.

Ammann, M., Pöschl, U., and Rudich, Y.: Effects of reversible adsorption and Langmuir-Hinshelwood surface reactions on gas uptake by atmospheric particles, Phys. Chem. Chem. Phys., 5, 351-356, 2003.

Andreae, M. O. and Rosenfeld, D.: Aerosol-cloud-precipitation interactions. Part 1, The nature and sources of cloud-active aerosols, Earth-Sci. Rev., 89, 13-41, 2008.
Atkinson, R. and Arey, J.: Atmospheric chemistry of gas-phase polycyclic aromatic-hydrocarbons - Formation of atmospheric mutagens, Environ. Health Persp., 102, 117-126, 1994.

Bertram, A. K., Ivanov, A. V., Hunter, M., Molina, L. T., and Molina, M. J.: The reaction probability of $\mathrm{OH}$ on organic surfaces of tropospheric interest, J. Phys. Chem. A, 105, 94159421, 2001.

Donaldson, D. J., Mmereki, B. T., Chaudhuri, S. R., Handley, S., and Oh, M.: Uptake and reaction of atmospheric organic vapours on organic films, Faraday Discuss., 130, 227-239, 2005.

Dubowski, Y., Vieceli, J., Tobias, D. J., Gomez, A., Lin, A., Nizkorodov, S. A., McIntire, T. M., and Finlayson-Pitts, B. J.: Interaction of gas-phase ozone at $296 \mathrm{~K}$ with unsaturated self-assembled monolayers: A new look at an old system, J. Phys. Chem. A, 108, 10473-10485, 2004.

Finlayson-Pitts, B. J. and Pitts, J. N.: Chemistry of the upper and lower atmosphere, Academic Press, 2000.

Fuzzi, S., Andreae, M. O., Huebert, B. J., Kulmala, M., Bond, T. C., Boy, M., Doherty, S. J., Guenther, A., Kanakidou, M., Kawamura, K., Kerminen, V.-M., Lohmann, U., Russell, L. M., and Pöschl, U.: Critical assessment of the current state of scientific knowledge, terminology, and research needs concerning the role of organic aerosols in the atmosphere, climate, and global change, Atmos. Chem. Phys., 6, 2017-2038, 2006, http://www.atmos-chem-phys.net/6/2017/2006/.

Gross, S. and Bertram, A. K.: Reactive Uptake of $\mathrm{NO}_{3}, \mathrm{~N}_{2} \mathrm{O}_{5}$, $\mathrm{NO}_{2}, \mathrm{HNO}_{3}$, and $\mathrm{O}_{3}$ on Three Types of Polycyclic Aromatic Hydrocarbon Surfaces, J. Phys. Chem. A, 112, 3104-3113, 2008.

Hallquist, M., Wenger, J. C., Baltensperger, U., Rudich, Y., Simpson, D., Claeys, M., Dommen, J., Donahue, N. M., George, C., Goldstein, A. H., Hamilton, J. F., Herrmann, H., Hoffmann, T., Inuma, Y., Jang, M., Jenkin, M. E., Jimenez, J. L., Kiendler-Scharr, A., Maenhaut, W., McFiggans, G., Mentel, Th. F., Monod, A., Prévôt, A. S. H., Seinfeld, J. H., Surratt, J. D., Szmigielski, R., and Wildt, J.: The formation, properties and impact of secondary organic aerosol: current and emerging issues, Atmos. Chem. Phys., 9, 5155-5235, 2009, http://www.atmos-chem-phys.net/9/5155/2009/.

Hansen, J., Sato, M., and Ruedy, R.: Radiative forcing and climate response, J. Geophys. Res.-Atmos., 102, 6831-6864, 1997.

Homann, K. H.: Fullerenes and soot formation - New pathways to large particles in flames, Angew. Chem. Int. Edit., 37, 24352451, 1998.

IUPAC: Compendium of Chemical Terminology, 2nd edition (the "Gold Book"), edited by: Wilkinson, A. D. M. A. A., Blackwell Scientific Publications, Oxford, 1997.

Ivanov, A. V., Trakhtenberg, S., Bertram, A. K., Gershenzon, Y. M., and Molina, M. J.: $\mathrm{OH}, \mathrm{HO}_{2}$, and ozone gaseous diffusion coefficients, J. Phys. Chem. A, 111, 1632-1637, 2007.

Jacobson, M. Z.: A physically-based treatment of elemental carbon optics: Implications for global direct forcing of aerosols, Geophys. Res. Lett., 27, 217-220, 2000.

Kahan, T. F., Kwamena, N. O. A., and Donaldson, D. J.: Heterogeneous ozonation kinetics of polycyclic aromatic hydrocarbons on organic films, Atmos. Environ., 40, 3448-3459, 2006.

Kulmala, M., Asmi, A., Lappalainen, H. K., Carslaw, K. S., Pöschl, U., Baltensperger, U., Hov, Ø., Brenquier, J.-L., Pandis, S. N., Facchini, M. C., Hansson, H.-C., Wiedensohler, A., and O'Dowd, C. D.: Introduction: European Integrated Project on 
Aerosol Cloud Climate and Air Quality interactions (EUCAARI) - integrating aerosol research from nano to global scales, Atmos. Chem. Phys., 9, 2825-2841, 2009, http://www.atmos-chem-phys.net/9/2825/2009/.

Kuwata, M., Kondo, Y., Mochida, M., Takegawa, N., and Kawamura, K.: Dependence of CCN activity of less volatile particles on the amount of coating observed in Tokyo, J. Geophys. Res., 112, D11207, doi:10.1029/2006JD007758, 2007.

Kwamena, N. O. A., Earp, M. E., Young, C. J., and Abbatt, J. P. D.: Kinetic and product yield study of the heterogeneous gas-surface reaction of anthracene and ozone, J. Phys. Chem. A, 110, 36383646, 2006.

Kwamena, N. O. A., Staikova, M. G., Donaldson, D. J., George, I. J., and Abbatt, J. P. D.: Role of the aerosol substrate in the heterogeneous ozonation reactions of surface-bound PAHs, J. Phys. Chem. A, 111, 11050-11058, 2007.

Kwamena, N. O. A., Thornton, J. A., and Abbatt, J. P. D.: Kinetics of surface-bound benzo[a]pyrene and ozone on solid organic and salt aerosols, J. Phys. Chem. A, 108, 11626-11634, 2004.

Lammel, G., Sehili, A. M., Bond, T. C., Feichter, J., and Grassl, H.: Gas/particle partitioning and global distribution of polycyclic aromatic hydrocarbons - A modelling approach, Chemosphere, 76, 98-106, 2009.

Lee, J. Y. and Kim, Y. P.: Source apportionment of the particulate PAHs at Seoul, Korea: impact of long range transport to a megacity, Atmos. Chem. Phys., 7, 3587-3596, 2007, http://www.atmos-chem-phys.net/7/3587/2007/.

Liu, Y., Sklorz, M., Schnelle-Kreis, J., Orasche, J., Ferge, T., Kettrup, A., and Zimmermann, R.: Oxidant denuder sampling for analysis of polycyclic aromatic hydrocarbons and their oxygenated derivates in ambient aerosol: Evaluation of sampling artefact, Chemosphere, 62, 1889-1898, 2006.

Marchand, N., Besombes, J. L., Chevron, N., Masclet, P., Aymoz, G., and Jaffrezo, J. L.: Polycyclic aromatic hydrocarbons (PAHs) in the atmospheres of two French alpine valleys: sources and temporal patterns, Atmos. Chem. Phys., 4, 1167-1181, 2004, http://www.atmos-chem-phys.net/4/1167/2004/.

Masel, R. I.: Principles of adsorption and reaction on solid surfaces, John Wiley \& Sons, 1996.

McCabe, J. and Abbatt, J. P. D.: Heterogeneous Loss of Gas-Phase Ozone on n-Hexane Soot Surfaces: Similar Kinetics to Loss on Other Chemically Unsaturated Solid Surfaces, J. Phys. Chem. C, 113, 2120-2127, 2009.

Messerer, A., Rothe, D., Niessner, R., and Pöschl, U.: Kinetic observations and model calculations on continuous regeneration of NFZ diesel carbon particle precipitation systems, Chem.-Ing.Tech., 77, 881-886, 2005.

Mikhailov, E., Vlasenko, S., Martin, S. T., Koop, T., and Pöschl, U.: Amorphous and crystalline aerosol particles interacting with water vapor - Part 1: Microstructure, phase transitions, hygroscopic growth and kinetic limitations, Atmos. Chem. Phys. Discuss., 9, 7333-7412, 2009,

http://www.atmos-chem-phys-discuss.net/9/7333/2009/.

Mikhailov, E. F., Vlasenko, S. S., Podgorny, I. A. and Ramanathan, V.: Optical properties of soot-water drop agglomerates: An experimental study, J. Geophys. Res.-Atmos., 111, 16, 2006.

Mmereki, B. T. and Donaldson, D. J.: Direct observation of the kinetics of an atmospherically important reaction at the air-aqueous interface, J. Phys. Chem. A, 107, 11038-11042, 2003.
Mmereki, B. T., Donaldson, D. J., Gilman, J. B., Eliason, T. L., and Vaida, V.: Kinetics and products of the reaction of gas-phase ozone with anthracene adsorbed at the air-aqueous interface, Atmos. Environ., 38, 6091-6103, 2004.

Nelander, B. and Nord, L.: Do ozone-olefin complexes really exist, J. Am. Chem. Soc., 101, 3769-3770, 1979.

Pfrang, C., Shiraiwa, M., and Pöschl, U.: Coupling aerosol surface and bulk chemistry with a kinetic double layer model (K2-SUB): oxidation of oleic acid by ozone, Atmos. Chem. Phys. Discuss., 9, 26969-27019, 2009,

http://www.atmos-chem-phys-discuss.net/9/26969/2009/.

Pitts, J. N.: Formation and fate of gaseous and particulate mutagens and carcinogens in real and simulated atmospheres, Environ. Health Persp., 47, 115-140, 1983.

Pöschl, U.: Formation and decomposition of hazardous chemical components contained in atmospheric aerosol particles, J. Aerosol Med., 15, 203-212, 2002.

Pöschl, U.: Atmospheric aerosols: Composition, transformation, climate and health effects, Angew. Chem. Int. Edit., 44, 7520 7540, 2005.

Pöschl, U., Letzel, T., Schauer, C., and Niessner, R.: Interaction of ozone and water vapor with spark discharge soot aerosol particles coated with benzo[a]pyrene: $\mathrm{O}_{3}$ and $\mathrm{H}_{2} \mathrm{O}$ adsorption, benzo[a]pyrene degradation, and atmospheric implications, J. Phys. Chem. A, 105, 4029-4041, 2001.

Pöschl, U., Rudich, Y., and Ammann, M.: Kinetic model framework for aerosol and cloud surface chemistry and gas-particle interactions - Part 1: General equations, parameters, and terminology, Atmos. Chem. Phys., 7, 5989-6023, 2007, http://www.atmos-chem-phys.net/7/5989/2007/.

Prinn, R., Cunnold, D., Simmonds, P., Alyea, F., Boldi, R., Crawford, A., Fraser, P., Gutzler, D., Hartley, D., Rosen, R., and Rasmussen, R.: Global average concentration and trend for hydroxyl radicals deduced from ALE/GAGE trichloroethane (methyl chloroform) data for 1978-1990, J. Geophys. Res.-Atmos., 97, 24452461, 1992.

Rogaski, C. A., Golden, D. M., and Williams, L. R.: Reactive uptake and hydration experiments on amorphous carbon treated with $\mathrm{NO}_{2}, \mathrm{SO}_{2}, \mathrm{O}_{3}, \mathrm{HNO}_{3}$, and $\mathrm{H}_{2} \mathrm{SO}_{4}$, Geophys. Res. Lett., 24, 381-384, 1997.

Rudich, Y., Talukdar, R. K., Imamura, T., Fox, R. W., and Ravishankara, A. R.: Uptake of $\mathrm{NO}_{3}$ on $\mathrm{KI}$ solutions: rate coefficient for the $\mathrm{NO}_{3}+\mathrm{I}$-reaction and gas-phase diffusion coefficients for NO3, Chem. Phys. Lett., 261, 467-473, 1996.

Sadezky, A., Muckenhuber, H., Grothe, H., Niessner, R., and Pöschl, U.: Raman microspectroscopy of soot and related carbonaceous materials: Spectral analysis and structural information, Carbon, 43, 1731-1742, 2005.

Schauer, C.: Analysis and reactivity of polycyclic aromatic hydrocarbon in aerosol, Technical University of Munich, 2004.

Schauer, C., Niessner, R., and Pöschl, U.: Polycyclic aromatic hydrocarbons in urban air particulate matter: Decadal and seasonal trends, chemical degradation, and sampling artifacts, Environ. Sci. Technol., 37, 2861-2868, 2003.

Schauer, C., Niessner, R., and Pöschl, U.: Analysis of nitrated polycyclic aromatic hydrocarbons by liquid chromatography with fluorescence and mass spectrometry detection: air particulate matter, soot, and reaction product studies, Anal. Bioanal. Chem., 378, 725-736, 2004. 
Schwarz, J. P., Gao, R. S., Spackman, J. R., Watts, L. A., Thomson, D. S., Fahey, D. W., Ryerson, T. B., Peischl, J., Holloway, J. S., Trainer, M., Frost, G. J., Baynard, T., Lack, D. A., de Gouw, J. A., Warneke, C., and Del Negro, L. A.: Measurement of the mixing state, mass, and optical size of individual black carbon particles in urban and biomass burning emissions, Geophys. Res. Lett., 35, L13810, doi:10.1029/2008g1033968, 2008.

Segal-Rosenheimer, M. and Dubowski, Y.: Photolysis of thin films of cypermethrin using in situ FTIR monitoring: Products, rates and quantum yields, J. Photochem Photobio A, 200, 262-269, 2008.

Seinfeld, J. H. and Pandis, S. N.: Atmospheric chemistry and physics - From air pollution to climate change, John Wiley \& Sons, Inc., 1998.

Shiraiwa, M., Kondo, Y., Moteki, N., Takegawa, N., Miyazaki, Y., and Blake, D. R.: Evolution of mixing state of black carbon in polluted air from Tokyo, Geophys. Res. Lett., 34, L16803, doi:10.1029/2007g1029819, 2007.

Shiraiwa, M., Pfrang, C., and Pöschl, U.: Kinetic multi-layer model of aerosol surface and bulk chemistry (KM-SUB): the influence of interfacial transport and bulk diffusion on the oxidation of oleic acid by ozone, submitted, 2009.

Springmann, M., Knopf, D. A., and Riemer, N.: Detailed heterogeneous chemistry in an urban plume box model: reversible co-adsorption of $\mathrm{O}_{3}, \mathrm{NO}_{2}$, and $\mathrm{H}_{2} \mathrm{O}$ on soot coated with benzo[a]pyrene, Atmos. Chem. Phys., 9, 7461-7479, 2009, http://www.atmos-chem-phys.net/9/7461/2009/.
Stephens, S., Rossi, M. J., and Golden, D. M.: The heterogeneous reaction of ozone on carbonaceous surfaces, Int. J. Chem. Kinet., 18, 1133-1149, 1986.

Sullivan, R. C., Thornberry, T., and Abbatt, J. P. D.: Ozone decomposition kinetics on alumina: effects of ozone partial pressure, relative humidity and repeated oxidation cycles, Atmos. Chem. Phys., 4, 1301-1310, 2004, http://www.atmos-chem-phys.net/4/1301/2004/.

Tabor, K., Gutzwiller, L., and Rossi, M. J.: Heterogeneous chemical-kinetics of $\mathrm{NO}_{2}$ on amorphous-carbon at ambient temperature, J. Phys. Chem., 98, 6172-6186, 1994.

Thomas, E., Rudich, Y., Trakhtenberg, S., and Ussyshkin, R.: Water adsorption by hydrophobic organic surfaces: Experimental evidence and implications to the atmospheric properties of organic aerosols, J. Geophys. Res.-Atmos., 104, 16053-16059, 1999.

Vieceli, J., Roeselova, M., Potter, N., Dang, L. X., Garrett, B. C., and Tobias, D. J.: Molecular dynamics simulations of atmospheric oxidants at the air-water interface: Solvation and accommodation of $\mathrm{OH}$ and $\mathrm{O}_{3}$, J. Phys. Chem. B, 109, 15876-15892, 2005.

Wu, C. H., Salmeen, I., and Niki, H.: Fluorescence spectroscopic study of reactions between gaseous ozone and surface-adsorbed polycyclic aromatic-hydrocarbons, Environ. Sci. Technol., 18, 603-607, 1984. 